\title{
Knowledge resources and the acquisition of spinouts
}

\author{
Pamela Adams ${ }^{1} \cdot$ Roberto Fontana $^{2,3} \cdot$ Franco Malerba $^{4}$ (D)
}

Received: 31 May 2021 / Revised: 16 November 2021 / Accepted: 30 December 2021 /

Published online: 21 February 2022

(c) The Author(s) 2022

\begin{abstract}
In high-technology industries, employee spinouts have increasingly been identified as attractive targets for acquisitions. Yet employee spinouts may originate from different knowledge contexts. This study adopts a resource base perspective to examine the impact of both the knowledge heritage and the product strategy of spinouts originating from different contexts (i.e. from the same industry or from a related downstream industry) on the potential to be acquired by firms in the same industry or in related industries. Our findings, based on data from the semiconductor industry and its related downstream industries, show that spinouts from firms in a focal industry represent appealing targets for a broad range of buyer firms from within the focal industry or from related, downstream industries, independent of their product strategy at entry. By contrast, spinouts from downstream, user industries that enter into an upstream industry, tend to appeal to a more limited set of buyers. Our study suggests that managers and academics should consider the acquisition of spinouts whose founders have origins in related industries as a channel to access critical knowledge from upstream or downstream contexts. Yet because many of the critical knowledge resources that spinouts possess are embodied in their founders, such acquisitions also require careful management of personnel decisions post-acquisition.
\end{abstract}

Keywords Acquisitions · Knowledge resources · Employee entrepreneurship · Employee spinout

\section{Introduction}

Entrepreneurial spinouts-independent ventures founded by the ex-employees of incumbent firms in an industry - are pervasive in many high-technology industries such as semiconductors, lasers, disk drives and medical devices (Adams et al., 2013; Agarwal et al., 2004; Christensen, 1997; Klepper \& Sleeper, 2005). Recent

Franco Malerba

franco.malerba@unibocconi.it

Extended author information available on the last page of the article 
scholarship on spinouts suggests that the pre-entry knowledge and experience inherited by these ventures through their founders provide them with resource advantages that serve as a source of both innovation and longevity with respect to other startups. In fact, studies across multiple industries show that spinouts outperform other startups in terms of both survival and peak market share (Agarwal et al., 2004; Helfat \& Lieberman, 2002; Klepper, 2002, 2009).

While there has been extensive study of how knowledge inheritance relates to the survival and performance of spinouts, little attention has been given in the literature to how knowledge inheritance relates to the acquisition of such ventures. This comes as a surprise given that the acquisition of startup ventures, including spinouts, increasingly characterize the dynamics in many high-technology industries (Andersson \& Xiao, 2016; Benson \& Ziedonis, 2009). Companies such as Cisco and Lucent (telecommunications), Johnson \& Johnson (medical devices) and IBM (computing and software) have used the acquisition of spinouts to establish positions in disruptive technologies (Christensen, 1997). In fact, as the innovative performance of new startups and spinout ventures has increased over recent decades, they have become attractive targets for buyer firms seeking to access new technologies and know-how outside of their existing firm boundaries (Ahuja \& Katila, 2001; Benson \& Ziedonis, 2009; Eisenhardt \& Martin, 2000; Helfat \& Eisenhardt, 2004). At the same time, startup ventures, including spinouts, often use acquisitions as exit strategies for their businesses (DeTienne, 2010). While exit through acquisition is often approximated to the failure of the startup venture, many entrepreneurs view such exit strategies as the ultimate fulfillment of the new venture process (McGrath and MacMillan, 2000; Wennberg \& DeTienne, 2014). A relevant question thus becomes whether and how the knowledge inheritance of spinouts affects acquisition patterns regarding spinouts both in terms of their potential to be acquired and the type of buyers that acquire them.

In this study we begin to tackle this question by examining the likelihood of different types of spinouts to be acquired by buyer firms in the same or a related industry. More specifically we ask how the knowledge resources and capabilities of entrepreneurial spinouts, inherited through their founders, affect their potential to be acquired by different types of buyer firms. Building on the literature on entrepreneurship and the resource-based theory (Barney, 1991; Teece et al., 1997), we distinguish between spinouts according to the origins of their founders. Research shows that spinouts may originate from different knowledge contexts and that such differences affect both the strategies and performance of these ventures (Adams et al., 2019; Agarwal \& Shah, 2014). Here we focus on spinouts from both the focal industry itself and from related, downstream industries. In the latter case, these are independent ventures that originate in a user industry and cross industry boundaries to enter an upstream industry (Adams et al., 2016). Yet just as spinouts may come from related industries, so too may buyer firms. Therefore, we also distinguish between two types of buyer firms in parallel with our typology of spinout firms: buyers from the focal industry and buyers from downstream, user industries. While buyers from the focal industry are acquiring a competitor within their same industry, buyers from downstream industries are engaged in vertical integration. We propose that this distinction will affect both the kinds of resources buyer firms possess and 
the kinds of resources that they might search for in a target firm (Graebner et al., 2010; Villalonga \& McGahan, 2005). Finally we consider the product strategies of both buyer and target firms. We develop a set of hypotheses and test them empirically in the context of the US semiconductor industry. We first identify the full population of independent startups in the industry between 1996 and 2007 and classify them according to the origins of their founders. We then trace the history of these firms to 2014 in order to identify which ventures were acquired within this time period and by whom. The final dataset analyzed consists of 395 acquisitions, with an average age of the spinout at the time of acquisition of 6 years.

We find confirmation for our hypotheses that spinouts that originate from distinct knowledge contexts have a different potential to be acquired by distinct categories of buyers. Compared to de novo startups, spinouts from the focal industry have a higher potential to be acquired by a wide range of buyer firms, independent of their product strategy at entry. These findings suggest that knowledge heritage clearly matters in terms of the acquisition potential of spinout ventures. However, the acquisition potential of spinouts from downstream industries that enter an upstream, focal industry is shown to be dependent both on their heritage and on their product strategy. Only those spinouts from downstream, user industries that offer products targeted to specific market segments or applications are shown to be more attractive targets than other startups, and only for buyers whose product strategies match those of the target spinout.

Our study contributes new work to the literature on both entrepreneurship and acquisitions. By investigating how the knowledge context from which entrepreneurial firms originate may affect not only their survival rate, but also their potential to exit through acquisition, we extend research on entrepreneurship and evolutionary theory (Agarwal et al., 2004; Helfat \& Lieberman, 2002; Nelson \& Winter, 1982) to include exit strategies. We contribute to the literature on acquisitions by suggesting that the knowledge resources inherited by spinouts may act as an important source of heterogeneity in the selection choices of buyer firms.

\section{Theoretical framework and hypotheses}

\subsection{Acquisitions and employee spinouts}

Entrepreneurial spinouts, like other startups, often seek to exit their businesses through acquisition (Wennberg et al., 2010). Through an acquisition, the founders of a privately held firm remove themselves, in varying degrees, from the primary ownership of a company (DeTienne, 2010). The literature on spinouts has largely focused on entrepreneurial exit as a dichotomy, where exit is viewed as a negative result and survival is viewed as a positive outcome. Yet studies show that entrepreneurs themselves may actually view exit as the ultimate fulfillment of the new venture process (Wennberg \& DeTienne, 2014). Even further, as new ventures are increasingly pressured to include exit strategies in their initial business plans, many entrepreneurs identify acquisition as a viable option from the start of their businesses. Spinouts may also look to an acquisition as a means to gain access to 
external financing (Carpenter \& Petersen, 2002; Colombo \& Grilli, 2007). In fact, such ventures often suffer from limited access to financing, due in part to problems related to information asymmetries between small, privately owned firms and capital markets (Hall, 2002). An acquisition is therefore treated as a strategy to allow the firm to survive and grow when the entrepreneur is unable to raise sufficient capital. Given the strategic importance of acquisitions for entrepreneurial ventures, it is important to examine the factors that may impact the potential of these entrepreneurs to sell their ventures, and to whom (Arora \& Nandkumar, 2011).

We propose that important insights into these factors may be drawn from the resource-based view of the firm. Resource-based theory posits that competitive advantage stems from the resources and capabilities of firms (Barney, 1991; Teece et al., 1997). Two critical elements of this theory involve resource heterogeneity and resource immobility: firms differ in the bundle of resources and capabilities that they possess and these bundles tend to be 'sticky' and hard to transfer from one firm to another (Barney, 1991; von Hippel, 1994). This is especially true in high-technology industries where knowledge is often complex, tacit, and embedded in individuals and relationships (Kogut \& Zander, 1992; Ranft \& Lord, 2002). Drawing on this literature, recent scholarship on acquisitions suggests that acquisitions have the potential not only to enhance scale economies (Singh \& Montgomery, 1987) and build market power, but also to allow firms to access and deploy new knowledge and capabilities (Capron \& Mitchell, 2009; Karim \& Mitchell, 2009; Kaul \& Wu, 2016). Because the extent to which these knowledge resources may be exchanged on the market or shared through alliances is limited, acquisition often represents a strategic alternative for firms to access new resources in another firm (Arora et al., 2004; Dyer et al., 2004). It has been shown, in fact, that buyers use acquisitions not only to secure specific products or technologies that are owned or being developed by target companies, but also to access the know-how and capabilities embedded in the people in these firms (Christensen, 1997; Graebner, 2004; Ranft \& Lord, 2002). Examining the resources and capabilities of entrepreneurial spinouts may therefore help us to understand what these ventures may offer to potential buyers.

But research on acquisitions also suggests that acquisitions are based on dyadic information (Wang \& Zajac, 2007). Buyer firms do not select potential targets solely on the basis of the resource characteristics of the target firm. Rather, they look at these characteristics in relation to themselves (Yu et al., 2016). As a result, the interest of different buyer firms in a particular spinout may vary according to the profile of the buyer firm. We therefore propose that the potential for entrepreneurial spinouts to be acquired by particular buyers will depend in part on the characteristics of the resources and capabilities possessed by the spinout, and in part on the characteristics of those possessed by the buyer firm. We also propose that the knowledge resources of some types of spinouts will appeal to a broader range of buyer firms than those of other types of spinouts. 


\subsection{A typology of spinouts based on knowledge resources and product strategy}

Entrepreneurial spinouts, also referred to as employee spinouts or spinoffs, are defined as new and independent entrepreneurial ventures founded by the ex-employees of existing firms in an industry. Research over a broad range of industries suggests that the pre-entry experience and know-how inherited by spinouts through their founders play a significant role in determining both their strategic choices at entry and their ability to survive over time (Agarwal et al., 2004; Brüderl et al., 1992; Chatterji, 2009; Chen et al., 2012; Franco \& Filson, 2006; Klepper, 2001; Klepper \& Sleeper, 2005). The knowledge heritage of spinouts makes them different from other startups, such as de novo entrants and university spinoffs (Clarysse et al., 2011; Feldman et al., 2002; Shane, 2004; Vohora et al., 2004; Wennberg et al., 2011), in terms of their ability to recognize and exploit new sources of knowledge (Agarwal et al., 2004; Chatterji, 2009; Shane \& Khurana, 2003). The effects of knowledge heritage also appear to persist over time, enabling spinouts to enact and adapt to changes in an industry environment even subsequent to entry (Dencker et al., 2009).

New and independent ventures created by the ex-employees of incumbent firms in the same industry are referred to as 'focal spinouts' (Agarwal et al., 2004; Klepper \& Sleeper, 2005). Examples of such spinouts may be found in multiple hightechnology industries. In semiconductors, Cascade Semiconductor Corporation was founded by a team of former employees of Intel who sought to build upon their expertise in SRAM development to specialize in memories for the mobile phone industry. In medical devices, Origin Medsystems (laparoscopic surgical devices) was founded by an ex-employee of Microgenics Corporation, the producer of a broad range of analytic instruments and equipment for medical use. In telecommunications, Ascend was started by four employees that left Hayes Microcomputer Products, a US based manufacturer of modems, to enter the ISDN aggregator market. ${ }^{1}$ Focal spinouts represent a distinct category of startups studied by scholars seeking to understand how knowledge inheritance may affect both the entry choices and the survival rates of new ventures (Helfat \& Lieberman, 2002; Klepper, 2009).

Yet, while most of the scholarship on spinouts refers to new ventures that remain within the same industry, research also shows that new firms may enter a focal industry from 'knowledge contexts' outside of the incumbent industry (Agarwal \& Shah, 2014; Frischmann et al., 2014; Wennberg et al., 2010). In a value-chain perspective, these knowledge contexts include downstream, user industries. New ventures that are created when the employees of firms in downstream industries leave their prior employment to create new and independent firms in the upstream, focal industry are referred to as 'user-industry spinouts' (Adams et al., 2016). These new ventures are defined as spinouts since they are entrepreneurial ventures founded by ex-employees of an incumbent firm (Agarwal et al., 2004; Klepper, 2001). Their industry of origin,

\footnotetext{
${ }^{1}$ It is interesting to note for this study that all three of these spinouts eventually exited through an acquisition. Cascade Semiconductors was bought by Cypress Semiconductor, Origin Medsystems was bought by Eli Lilly, and Ascend was acquired by Lucent.
} 
however, is not the same, focal industry, but a downstream, user industry. They thus enter an upstream industry with deep and contextual knowledge about applications and users in a downstream industry, and about how the products produced upstream are used and integrated by downstream firms in their final products or services. ${ }^{2}$ Studies show that user-industry spinouts may represent a significant share of new entrants in diverse high technology industries (Adams et al., 2013, 2019).

According to our categorization, the profiles of spinout ventures are defined by the knowledge resources and capabilities inherited through their founders from their pre-entry experience in either a focal industry or a downstream, user industry. Research shows, however, that understanding the strategic value of firms for acquisitions may require a multidimensional perspective in which the resources and capabilities of firms are assessed along more than one dimension (Kaul \& Wu, 2016; Tanriverdi \& Venkatraman, 2005; Zaheer et al., 2013). According to such a perspective, multiple dimensions, each independent of the others, may coalesce in different ways to form distinct combinations of resources and capabilities in different firms. In this study, we consider two dimensions. The first is the industry context of origin as described above. The second is the product strategy of the spinouts at the time of entry. Recent research suggests that the knowledge resources inherited by spinouts through their founders work both to define and constrain the product strategies of such new ventures (Agarwal et al., 2004; Chatterji, 2009; Clarysse et al., 2011; Helfat \& Lieberman, 2002; Khessina \& Carroll, 2008). Examining the product choices that spinouts make as they enter an industry may thus provide a fuller indication of the types of knowledge resources with which it intends to compete. We distinguish between two different product strategies: generic and market-specific products. Generic products refer to products that may be sold into multiple markets with no need for customization or adaptation. Such products in these markets respond to generic needs across a wide range of customer categories.

Based on these distinctions, we develop a typology of spinouts based on both the knowledge context from which their founders originate and their product strategies at the time of entry into a focal industry. The following table presents four combinations of knowledge heritage and entry strategy: (1) focal spinouts that enter generic products; (2) user-industry spinouts that enter generic products; (3) focal spinouts that enter market-specific products; (4) user-industry spinouts that enter market-specific products (see Fig. 1). We then use this typology to compare and contrast the potential of different spinout types to be acquired.

\subsection{Buyer firm characteristics}

Just as spinouts may come from different industry contexts and produce different types of products, so too might buyer firms. In this study, we distinguish between two types of buyer firms in parallel with our typology of spinout firms: buyers from

\footnotetext{
${ }^{2}$ An example of user-industry spinout is Sequans Communications. This company competes in semiconductors, but was founded by an entrepreneur from Jupiter Networks, an incumbent in the networking industry, a downstream user of semiconductor chips.
} 


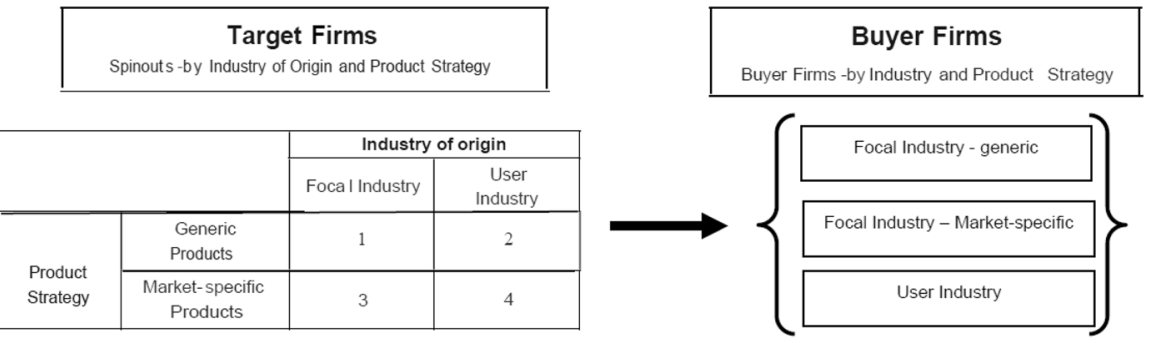

Fig. 1 Classification of target firms and buyer firms

the focal industry and buyers from downstream, user industries. Buyers from the focal industry acquire a competitor within their same industry. As a result, they may extend their products and technologies and expand their market power in the focal industry. By contrast, buyers from downstream industries are engaging in vertical integration. Such acquisitions will therefore result in a change in the roster of participants in the focal industry by adding integrated firms that compete in multiple markets and industries. As in our typology of spinouts, buyers from the focal industry may be characterized by the different product categories (generic vs. market-specific) in which they are active. As a result, we compare and contrast the potential for each of our spinout types to be acquired by three different kinds of buyer firms: (a) firms in the focal industry focused on generic products; (b) firms in the focal industry focused on market-specific products; (c) and firms in downstream, user-industries (see Fig. 1). ${ }^{3}$

\subsection{The acquisition of different types of spinouts}

We now examine the potential for a match between different types of buyers with different types of spinouts. The question we pose is: what is the likelihood that a particular type of spinout will be acquired by any of the three categories of buyer firms that we have identified? We begin by looking at focal spinouts.

Research suggests that spinouts from incumbent firms in the same industry inherit multiple types of knowledge from their parents. These include both codified and tacit forms of technological knowledge (Agarwal et al., 2004; Teece, 1986), market knowledge related to customer needs (Agarwal et al., 2004; Buenstorf, 2007; Shane, 2000; Tripsas, 2008), and industry knowledge concerning organizational practices, regulations, and competitors (Chatterji, 2009; Feldman et al., 2019). It is also argued that spinouts benefit as much from 'what they know' as from 'whom they know.' They may, in fact, inherit affiliations with prominent organizations (Higgins \& Gulati, 2003), social connections (Sorenson \& Audia, 2000), or contacts with important networks in the industry's ecosystem.

\footnotetext{
${ }^{3}$ No distinction is made for the product categories of buyers from user industries since they are not competing in the focal industry or within product categories of the focal industry.
} 
The above studies all suggest, therefore, that focal spinouts have informational advantages that distinguish them from other startups that lack relevant pre-entry experience in the focal industry.

For focal spinouts that produce generic products, these advantages will be broadly related to core technologies in the focal industry. Since generic products may be used across diverse application areas, such spinouts benefit from deep technological knowledge in focal product areas and marketing experience across multiple markets. The literature on markets for technology also suggests that firms with technologies that serve wider markets enjoy higher prospects for growth and performance (Arora \& Gambardella, 2010; Arora et al., 2001). As a result, spinouts that produce generic products should be attractive targets for a wide variety of firms in the focal industry seeking to access the knowledge resources embedded within these organizations. Their knowledge of core technologies and their ability to offer knowledge resources that may meet multiple needs or that have broad applications may also make them potential targets to buyers from downstream, user industries that seek to integrate vertically into the focal industry through an acquisition.

A similar logic may be applied for focal spinouts in market specific product categories. As focal spinouts, they are likely to be endowed with both technological and operational knowledge resources related to the focal industry. Different from focal spinouts in generic products, however, focal spinouts in marketspecific products target the needs of particular market segments. Such a strategy requires deeper knowledge of downstream users and applications for their products. Such resources may be developed through external contacts with customers, markets or industry experts and may support their ability to recognize customer needs and deliver on customer expectations. As a result, focal spinouts in marketspecific product categories possess knowledge resources that may be highly differentiated in nature and attractive to other firms in the focal industry that aim to enter specific market niches or to develop customized solutions for specific application areas. Such resources are also attractive for firms in user industries seeking to integrate vertically into the focal industry by acquiring a supplier firm that has the appropriate resources, and the appropriate mindset, to meet user needs for application specific solutions (Narver \& Slater, 1990). It therefore follows that both focal spinouts that produce generic products and those that produce market-specific products possess knowledge advantages for buyers in both the focal industry and related, downstream industries with respect to other de novo entrants that lack relevant industry experience in the focal industry. The nature of these advantages, moreover, makes them more attractive targets for buyer firms in either the focal industry or in related, user industries than for buyers from other contexts. We therefore propose that, with respect to the other de novo startups:

HYPOTHESIS 1 (H1): Spinouts from the focal industry that produce generic products are more likely to be acquired by buyer firms in both the focal and user industries than by other types of buyers.

HYPOTHESIS 2 (H2): Spinouts from the focal industry that produce market-specific products are more likely to be acquired by buyer firms in both the focal and user industries than by other types of buyers. 
We now turn our attention from focal spinouts to user-industry spinouts. For spinouts that cross industry boundaries, knowledge inheritance is linked to the industry from which the founders originate, which is different from the industry that they enter. In terms of technology, the knowledge that user-industry spinouts inherit regards the use of products from the upstream industry in downstream products and applications. Firms in user-industries are immersed in problem contexts that are concerned with the use of an intermediate product rather than with the production or commercialization of the intermediate product itself (Chatterji et al., 2009; Shah et al., 2012). They experience firsthand the functionality, as well as the shortcomings, of the upstream industry's products within their own application context (Chatterji \& Fabrizio, 2014; Smith \& Shah, 2013). As discussed above, focal spinouts may obtain some of this knowledge by working closely with their customers on specific applications and by integrating user knowledge into the product development processes of their organizations. However, the founders of user-industry spinouts benefit from contextual knowledge gained through their continuous and direct pre-entry experience with products or processes in user application areas (Chatterji \& Fabrizio, 2012, 2014; Tripsas, 2008; von Hippel, 1988). User-industry spinouts also inherit market knowledge in the downstream industry from which they originate. They may benefit from direct contact with other user firms in the downstream industry. They also may benefit from experience with distribution and communication channels in specific markets. Finally, in terms of industry knowledge, user-industry spinouts inherit knowledge resources with respect to specific regulations and relevant associations and networks at work in their industry of origin. The pre-entry experience of user-industry spinouts, therefore, provides them with unique informational advantages upon which to compete as a supplier in a related, upstream industry with respect to other 'de novo' startups that lack such experience.

User-industry spinouts that produce generic products have limited potential to capitalize on such advantages. Generic products do not necessarily require contextual knowledge of downstream applications. Rather, they tend to draw more upon core technological knowledge in the industry. Such knowledge, however, often requires significant time to develop, especially for firms that lack direct access to key resources and strategic information within the industry context. User-industry spinouts that have only recently crossed into the focal industry, therefore, may not have had sufficient time to develop the same levels of core technological knowledge possessed by established firms in the industry or by focal spinouts that benefit from their founder's pre-entry experience in the industry (Dierickx \& Cool, 1989). Finally, while they may have specific experience from one particular downstream user industry, they lack contextual experience with the focal industry's broader customer base. As a result, user-industry spinouts that produce generic products are not likely to be a valuable target for any specific type of buyer firm with respect to other 'de novo' startups. They have little to offer firms in the focal industry given their origins from a downstream industry and their lack of significant experience with core technological knowledge in the focal industry. Similarly, by choosing to compete in generic product categories, they do not offer buyers from user industries, other than those close to their origins, any particular knowledge or capabilities in 
downstream application areas. We therefore propose that, with respect to the other de novo startups:

HYPOTHESIS 3 (H3): Spinouts from user industries that produce generic products are not more likely to be acquired by buyer firms in either the focal or user industries than by other types of buyers.

Along similar lines, user-industry spinouts active in market specific product categories may not be interesting targets for all buyer firms in the focal industry. Buyer firms in the focal industry that produce generic products, in fact, are not likely to target such firms. Such buyers are less likely to benefit from the kinds of downstream knowledge and experience possessed by user-industry spinouts and may find little value in the level of technological knowledge they possess in the focal industry.

By contrast, user-industry spinouts that produce market-specific products may be interesting targets for focal firms in market-specific product categories. Such targets offer a source of direct knowledge that may defy articulation and may be 'sticky' to individuals who have been employed directly in downstream industry settings (von Hippel, 1994). Acquisition may therefore represent a strategic alternative for firms in the focal industry to access such knowledge (Arora et al., 2001; Dyer et al., 2004). User-industry spinouts that produce market-specific products may also be interesting to buyer firms in user industries seeking to acquire knowledge resources in the focal industry. Their technological knowledge may be less advanced than focal spinouts, but more easily absorbed by a user firm seeking to vertically integrate into the focal industry, especially if the downstream industry is close to that of the founder's industry of origin. Their contextual experience in both a downstream industry context and in the focal industry with market-specific products may also signal superior ability to understand specific downstream application areas, a capability to integrate downstream and upstream knowledge into products, and a willingness to develop solutions for specific user needs. We therefore propose that, with respect to the other de novo startups:

HYPOTHESIS 4a (H4a): Spinouts from user industries that produce marketspecific products are more likely to be acquired by buyer firms in the focal industry that produce generic products than by other buyers that produce other products.

HYPOTHESIS 4b (H4b): Spinouts from user industries that produce marketspecific products are more likely to be acquired by buyer firms in the focal industry that produce market-specific products or by buyer firms in user industries than by other buyers that produce other products.

\section{Empirical context: semiconductor industry}

The semiconductor industry offers a rich and highly dynamic environment in which to study the acquisitions of new ventures from different knowledge contexts. High levels of technological change and entrepreneurship have characterized the evolution of the industry since its birth in the 1950s (Brittain \& Freeman, 1986; Holbrook 
et al., 2000). In addition, acquisitions have become a prominent mechanism for accessing and deploying new knowledge in the semiconductor industry over recent decades (Kapoor \& Lim, 2007).

The early part of the industry's history was dominated by spinouts from the focal industry. The famous spinouts from Fairchild, the so-called 'Fairchildren', are cases in point. In more recent periods, however, entrepreneurship in semiconductors (Saxenian, 1996) has also involved innovative startups from downstream, user-firms (Adams et al., 2013; Fontana \& Malerba, 2010). Semiconductor devices became an increasingly strategic component in many user product categories, requiring greater levels of customization in chip design to meet the needs of specific applications and product lines. As technological developments in the industry lowered the barriers to entry in many product categories in semiconductors and opened up the range of potential entry strategies for new startups (Brown \& Linden, 2011), downstream user firms increasingly sought to gain access to the capabilities and technologies needed to design their own chips (Brown \& Linden, 2011) and spinouts from user firms began to enter competition in semiconductors. As a result, within the context of the semiconductor industry, we find new entrants from both the focal industry (semiconductors) and downstream user industries that possess valuable, yet distinctive, knowledge resources that could potentially represent key assets in acquisition choices. $^{4}$

\section{Data and estimation model}

\subsection{Data sources}

To test our hypotheses we combine information from several sources. The sample of startup firms is taken from a comprehensive dataset of semiconductor new ventures that entered the industry between 1997 and 2007. This dataset was provided by Semiconductor Times, a magazine published monthly by Pinestream Communications, a private consultancy company specialized in the semiconductor industry. The magazine records new startups in the industry each month and provides a profile of each company, including a description of their product offerings and activities. We consider this source, which has been used in prior research, both exhaustive and reliable (Adams et al., 2016).

The fate of each startup in terms of survival or exit was tracked until November 2014. In cases of acquisition, we were able to identify the buyer firm through LexisNexis. We then collected information on the acquirers, including their product strategies, through IC Insights. Information on the characteristics of the acquisition deal

\footnotetext{
${ }^{4}$ It is interesting to note that there was a high degree of co-location between semiconductor firms and firms active in downstream industries. A high density of firms in the semiconductor industry tends to coincide with areas with a high density of firms in downstream, user industries (Adams, et al., 2017). Thus, there is a concrete possibility that acquisitions, therefore, were also associated with location economies.
} 
Table 1 Breakdown of the sample by knowledge heritage and type of product

\begin{tabular}{lllll}
\hline Type of firm & \multicolumn{4}{l}{ Type of product } \\
\cline { 2 - 5 } & Generic & Specific & Other & Total \\
\hline Focal spinout & 70 & 84 & 32 & 186 \\
User-industry spinout & 19 & 80 & 9 & 108 \\
Other de-novo & 35 & 35 & 31 & 101 \\
Total & 124 & 199 & 72 & 395 \\
\hline
\end{tabular}

such as deal type, purpose, size, and overall value (when available) was gathered from Factset. The main SIC and/or NAICS codes necessary for classifying the buyer firm were retrieved through Orbis. Our final dataset of acquired firms includes 395 (or $42.2 \%$ ) of the 936 firms in the original dataset.

\subsection{Variables}

The first step in our empirical analysis is the identification of the knowledge heritage and product entry strategy of acquired (i.e. the targets) firms, as well as the identification of industry buyers and their product strategy.

Consistent with the arguments developed in Adams et al. (2016) we have identified the knowledge heritage of the targets by their industry of origin and then identified their product strategy. Their product strategy was identified by their product line at entry under the assumption that, given their young age and relative lack of resources, new entrants will initially focus on a single product line.

Depending on their knowledge heritage, targets are defined as: FOCAL SPINOUTS (186 or $47 \%$ of the sample) if they were founded by entrepreneurs whose last employment was in a semiconductor firm; USER-INDUSTRY SPINOUTS (108 or $27.4 \%$ of the sample) if they were founded by entrepreneurs who were previously employed in industries that use semiconductors as components in their final products; OTHER DE-NOvo (101 or $25.6 \%$ of the sample). Depending on the product market they enter targets can operate in: GENERIC SEMICONDUCTORS (124 or $31.3 \%$ of the sample) if they produce devices used in a wide range of systems and designed without a specific application in mind, SPECIFIC SEMICONDUCTORS (199 or 50\% of the sample) if they work on solutions tailored to specific users in specific submarkets (i.e. computing, communication, storage), OTHER SEMICONDUCTORS (72 or $18.7 \%$ of the sample) if they are active in other semiconductor areas such as customized ASIC design services and electronic design automation (EDA) tools. Table 1 reports the breakdown of start-ups by knowledge heritage and type of product.

A relatively higher share of user-industry spinouts $(80 / 108$ or $74 \%$ of the total in this category) enter specific semiconductors. Focal spinouts also enter into specific product categories (84/186 or $45 \%$ of the entrants in this category), although they tend to enter into generic semiconductors more than user-industry spinouts $(70 / 186$ or $37.6 \%$ vs. $19 / 108$ or $17 \%$ for the latter). Indeed, focal spinouts account for the majority of entrants into generic products $(70 / 124$ or $56 \%)$. It is interesting to note that 'other de-novo' entrants distribute almost equally across the three categories 
Table 2 Breakdown of the sample by type of entrant, type of product, and type of buyer

\begin{tabular}{|c|c|c|c|c|c|c|}
\hline & \multicolumn{3}{|c|}{ Semiconductor buyer } & \multirow[t]{2}{*}{ User buyer } & \multirow[t]{2}{*}{ Other buyer } & \multirow[t]{2}{*}{ Total } \\
\hline & Generic & Specific & Other & & & \\
\hline \multicolumn{7}{|c|}{ Type of firm } \\
\hline \multicolumn{7}{|c|}{ Focal spinouts } \\
\hline Generic & 13 & 19 & 13 & 20 & 5 & 70 \\
\hline Specific & 19 & 28 & 1 & 30 & 6 & 84 \\
\hline Other & 3 & 2 & 2 & 7 & 18 & 32 \\
\hline \multicolumn{7}{|c|}{ User-industry spinouts } \\
\hline Generic & 8 & 4 & 0 & 5 & 2 & 19 \\
\hline Specific & 12 & 31 & 3 & 25 & 9 & 80 \\
\hline Other & 1 & 1 & 0 & 3 & 2 & 9 \\
\hline \multicolumn{7}{|c|}{ Other de-novo } \\
\hline Generic & 7 & 6 & 3 & 13 & 6 & 35 \\
\hline Specific & 8 & 13 & 1 & 10 & 3 & 35 \\
\hline Other & 5 & 4 & 2 & 7 & 13 & 31 \\
\hline Total & 76 & 108 & 25 & 120 & 64 & 395 \\
\hline
\end{tabular}

of products (35\% in generic and specific, $30 \%$ in other semiconductors) a finding which is consistent with the idea that knowledge heritage does not guide their product entry strategy.

Buyer firms were first coded on the basis of their industry of activity as identified by their primary SIC or NAICS code and then assigned to one of the following three macro-categories using the logic explained in Adams et al. (2013): SEMICONDUCTOR BUYER (211 or $53 \%$ of buyers) if they belong to SIC code 3674 (until year 1999) and NAICS code 33441 for the subsequent years; USER BUYER (120 or 30.3\% of buyers) if they belong to one of the following downstream industries: industrial and commercial machinery (also including electric, gas, and sanitary services); computer and office equipment; electronic and other electrical equipment and components; telecommunications (also including communication services); automotive (also including transportation equipment); instrumentation (also including medical instruments); aerospace and defense ${ }^{5}$; OTHER BUYER (64 or $16.7 \%$ of buyers).

To test hypotheses $\mathrm{H} 4 \mathrm{a}$ and $\mathrm{H} 4 \mathrm{~b}$ semiconductor buyers have also been assigned to one of the following categories according to their own product strategy: SEMICONDUCTOR GENERIC-BUYERS (77 or $36.6 \%$ of semiconductor buyers); SEMICONDUCTOR SPECIFIC-BUYERS (109 or $51.6 \%$ of semiconductor buyers); SEMICONDUCTOR OTHER-BUYERS ( 25 or $11.8 \%$ of semiconductor buyers). ${ }^{6}$ Table 2 reports the breakdown of the

\footnotetext{
${ }^{5}$ See Table 10 in the Appendix for the list of corresponding SIC and NAICS codes for these industries.

${ }^{6}$ Information on the shares of revenues at the time of acquisition has been collected from IC Insights. We have identified as SEMICONDUCTOR GENERIC-BUYERS those firms whose highest share of revenues comes from areas such as memories (DRAM, Flash, SRAM, and other) and processors (including microprocessors, microcontrollers, and DSP). We have identified as SEMICONDUCTOR SPECIFIC-BUYERS those firms whose
} 
start-ups in our sample by type of buyer. This table allows us to make some preliminary observations concerning the relationship between the knowledge heritage of the target firms and the type of buyer.

The first observation concerns the distribution of the potential targets across type of buyers. The data shows that focal spinouts distribute more evenly than user-industry spinouts. Indeed, 65/99 (or 66\%) of user-industry spinouts are acquired by only two types of buyers (semiconductor firms producing market specific product or user buyers). This number is lower for focal spinouts (97/154 or 63\%) suggesting that focal spinouts appealing to more types of buyers. The second observation refers to the 'destination industry' of user-industry spinouts active in specific products. Such spinouts seem relatively more likely to be acquired by two types of buyers: semiconductor firms active in specific product categories and user-industry firms. Together these two types of buyers account for 56/80 (or 70\%) of the acquisitions of userindustry spinouts active in specific semiconductors.

Our list of controls includes two sets of variables. The first set accounts for the characteristics of the target firm and its founder. We control for the sIzE of the target firm as measured by the (logarithm of) total number of employees at the time of entry. Prior studies have found that there are benefits from firm size as relatively larger startups generally experience higher survival rates. However, prior studies have also found a positive correlation between size and exit by acquisition for those startups that do not survive (Arora \& Nandkumar, 2011). Thus, we consider firm size a proxy for the quality of the human capital of the target firm. We also account for potential diminishing return to size of the target by including a squared-term in our specifications. ${ }^{7}$

An additional measure of the quality of a venture is the innovative activity of the target firm. Prior studies have highlighted that innovative firms (if they do not survive) have a higher probability of exiting by acquisition (Arora \& Nandkumar, 2011; Cockburn \& MacGarvie, 2011; Hsu \& Ziedonis, 2013). In our study, we measure innovativeness in terms of patenting. Specifically, the variable PATENT is equal to one if, at entry, the startup had filed at least one patent with the US Patent and Trademark Office (USPTO), and zero otherwise. Finally, we control for whether or not the target semiconductor firm is a fabless. The dummy variable FABLESS is equal to one if the firm is only engaged in design and zero otherwise.

Our controls for the characteristics of the founder(s) include: SERIAL ENTREPRENEUR which is equal to one if the founder, or a member of the founding team, has

\footnotetext{
Footnote 6 (continued)

highest share of revenues comes from chips that are targeted at specific application markets (i.e. communications, consumer products, computation and storage, industrial products). OTHER SEMICONDUCTORS BUYERS those firms whose highest share of revenues comes from customized ASIC design services and electronic design automation (EDA) tools.

7 Consistent with the logic of our argument, the rationale for choosing size at entry as control is that this variable is supposed to capture additional assets related to human capital, either than the firm's prior knowledge heritage, that may confer specific endowments to firms at entry. In further specifications, not reported here for the sake of brevity, we have also controlled for size at exit, as proxied by firms' age at exit. Results remain unchanged.
} 
Table 3 Variables list and summary statistics

\begin{tabular}{lllrlll}
\hline Variable & Type & \#Observations & Mean & SD & Min & Max \\
\hline Semi buyer & Dummy & 395 & 0.534 & 0.499 & 0 & 1 \\
User buyer & Dummy & 395 & 0.304 & 0.460 & 0 & 1 \\
Other buyer & Dummy & 395 & 0.162 & 0.369 & 0 & 1 \\
Semi generic buyer & Dummy & 395 & 0.195 & 0.397 & 0 & 1 \\
Semi specific buyer & Dummy & 395 & 0.276 & 0.448 & 0 & 1 \\
Semi other buyer & Dummy & 395 & 0.063 & 0.244 & 0 & 1 \\
Focal spinout & Dummy & 395 & 0.471 & 0.500 & 0 & 1 \\
User-industry spinouts & Dummy & 395 & 0.273 & 0.446 & 0 & 1 \\
Other de novo & Dummy & 395 & 0.256 & 0.437 & 0 & 1 \\
Generic semi & Dummy & 395 & 0.314 & 0.465 & 0 & 1 \\
Specific semi & Dummy & 395 & 0.504 & 0.501 & 0 & 1 \\
Other semi & Dummy & 395 & 0.182 & 0.387 & 0 & 1 \\
Full acquisition & Dummy & 395 & 0.937 & 0.244 & 0 & 1 \\
Fabless & Dummy & 395 & 0.476 & 0.500 & 0 & 1 \\
PhD & Dummy & 395 & 0.387 & 0.488 & 0 & 1 \\
Serial entrepreneur & Dummy & 395 & 0.253 & 0.435 & 0 & 1 \\
Founding team & Dummy & 395 & 0.587 & 0.493 & 0 & 1 \\
Patent & Dummy & 395 & 0.372 & 0.484 & 0 & 1 \\
Size (Ln) & Continuous & 395 & 3.227 & 1.000 & 0 & 4.564 \\
Size sq (Ln) & Continuous & 395 & 11.413 & 4.413 & 0 & 20.833 \\
Exit year & Continuous & 395 & 2006.37 & 4.156 & 1997 & 2014 \\
Entry year & Continuous & 395 & 2000.304 & 2.395 & 1997 & 2007 \\
\hline & & & & &
\end{tabular}

previously founded another firm and zero otherwise; FOUNDING TEAM which is equal to one if the target firm is founded by a team of employees, and zero otherwise ${ }^{8}$; $\mathrm{PHD}$ which is equal to one if at least one member of the founding team possesses a doctoral degree. Indeed, previous research (Roberts, 1991) suggests that diminishing returns to firm's performance are triggered by an excessive amount of higher education.

The second set of controls includes the characteristics of the acquisition deal. In line with prior research on acquisitions (Puranam et al., 2003) we control for the size of the acquisition deal. Full ACQUISITION is equal to one if the deal involved $100 \%$ of the target firm (370 cases or $93.6 \%$ of the total) and zero otherwise.

\footnotetext{
${ }^{8}$ The classification of firms with a single founder did not represent a problem. To classify start-ups founded by a team of entrepreneurs we applied a 'majority rule' according to which when at least two founders were previously employed by a semiconductor firm, a downstream user firm, or a university or another organization, the firm was classified respectively as a 'focal spinouts', a 'user-industry spinout' or 'other de-novo'. To classify the remaining cases with founders from different backgrounds, we used the principle of the most influential founder (i.e., a founder with previous entrepreneurial experience and/ or previous innovative experience) as proposed in previous studies (Arora and Nandkumar 2011, Klepper 2007).
} 
Finally, in each regression we control for fixed effects linked to time of entry and exit, location of the target, and characteristics of the buyer not related to its industry and/or product strategy.

The complete list of our variables and their summary statistics are reported in Table 3

Most of the firms in our sample $(58.7 \%)$ have been founded by a team of entrepreneurs. In one fourth of the cases, at least one of the founders had prior experience as a founder (i.e. a 'serial entrepreneur') and in $38 \%$ of the cases one of the founders held a PhD. The average size of the firms in our sample is 25 employees in year 1 activity, while the average age is 6 years by the time of acquisition. The largest firm has 95 employees at the time of entry, which satisfies our threshold for being considered a startup (i.e. less than 100 employees). Forty-eight percent of the firms in the sample are fabless and only a minority (37\%) have filed for a patent at the USPTO at the time of entry. The latter evidence is consistent with the idea that firms in our sample possess few assets, other than their knowledge heritage, to offer buyers.

\subsection{Model specification}

We conceptualize the acquisition as the outcome of a selection process in which a target firm can be chosen by different types of buyers. We model the outcome of the process using the following multinomial logit equation:

$$
\operatorname{Pr}\left(y_{i}=j\right)=\frac{e^{\beta_{j}^{\prime} X_{i}}}{\sum_{k=0}^{n} e^{\beta_{k}^{\prime} X_{i}}}
$$

where $j$ indicates the type of buyer and $X_{i}$ is a vector of covariates capturing the characteristics of the target spinout $i$ as well as the control variables described above. We estimate two versions of (1). In the first estimation the type of buyer is defined only on the basis of the industry it belongs to: $j$ varies between 0 and $2(j=0$ for Semiconductor buyers, $j=1$ for User buyers, and $j=2$ for Other industry buyers). In the second estimation, the type of buyer is defined on the basis of a combination between the industry it belongs to and its products strategy (if it is a buyer from the focal industry): $j$ varies between 0 and $4(j=0$ for Semiconductor generic buyers, $j=1$ for Semiconductor specific buyers, $j=2$ for Semiconductor other buyer, $j=3$ for User buyers, and $j=4$ for Other industry buyers).

Table 4 reports the correlation coefficients among the variables. Coefficients in the correlation matrix do not seem to suggest that co-linearity is a problem in our data. This conclusion is supported by a mean value of the variance inflation factor (VIF) of 2.64.

\subsection{Results}

We present the results from the first estimate in Table 5. 


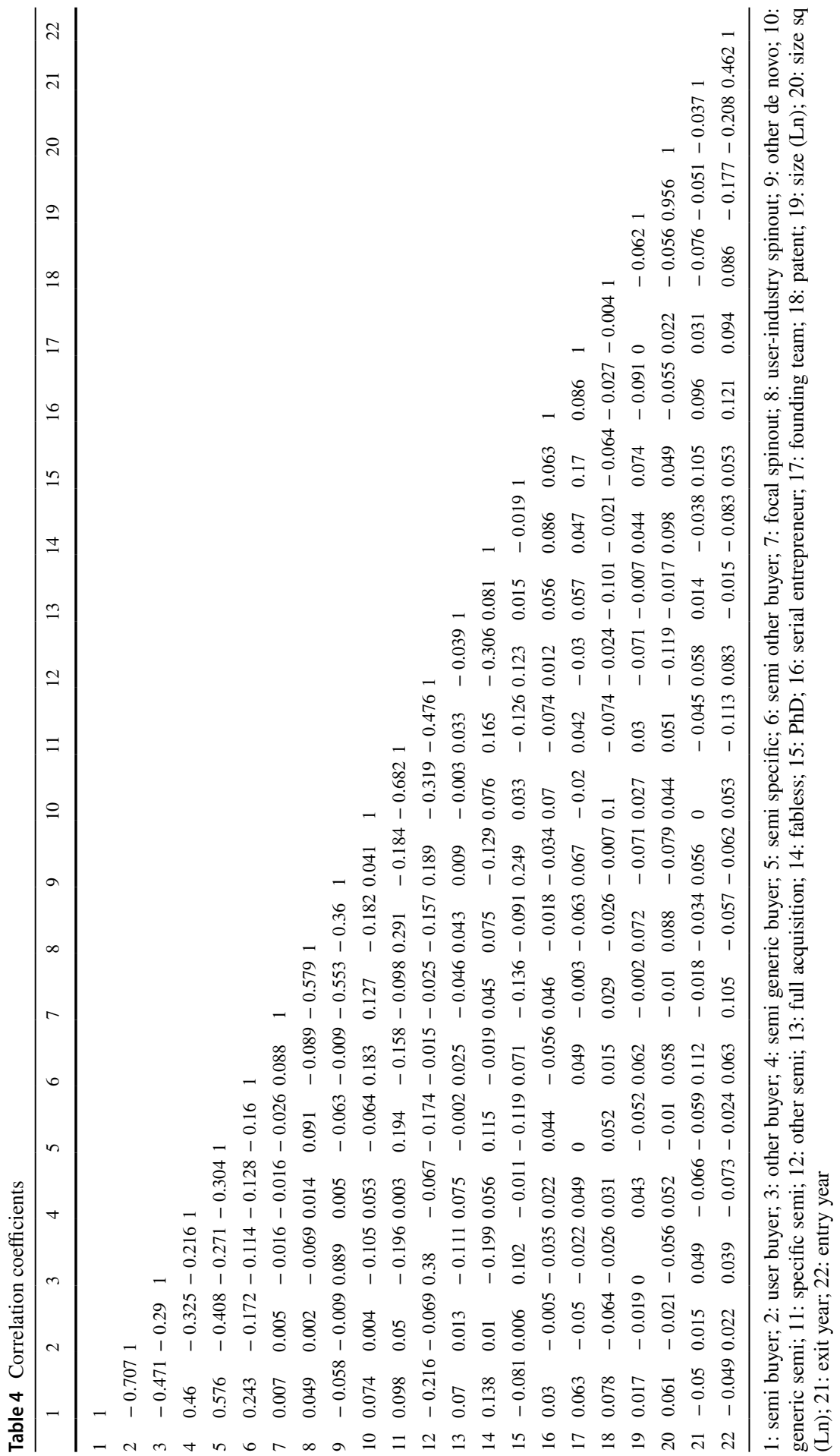


Table 5 Multinomial Logit regression - acquisition by categories of buyers

\begin{tabular}{|c|c|c|c|c|c|}
\hline \multirow[t]{3}{*}{ Variable } & \multirow[t]{3}{*}{ Interaction } & \multicolumn{2}{|l|}{ (1) } & \multicolumn{2}{|l|}{ (2) } \\
\hline & & \multicolumn{2}{|l|}{ Semi buyer } & \multicolumn{2}{|l|}{ User buyer } \\
\hline & & Coefficient & SE & Coefficient & SE \\
\hline \multirow[t]{3}{*}{ Focal spinout } & Generic semi & 2.311 & {$[0.782]^{* * *}$} & 2.057 & {$[0.796]^{* *}$} \\
\hline & Specific semi & 1.789 & {$[0.633]^{* * *}$} & 1.956 & {$[0.668]^{* * *}$} \\
\hline & Other semi & -1.051 & {$[0.725]$} & -0.689 & {$[0.676]$} \\
\hline \multirow[t]{3}{*}{ User-industry spinout } & Generic semi & 1.478 & {$[0.954]$} & 1.206 & [1.073] \\
\hline & Specific semi & 1.336 & {$[0.666]^{* * *}$} & 1.318 & {$[0.711]^{*}$} \\
\hline & Other semi & 0.730 & {$[1.080]$} & 1.166 & [1.069] \\
\hline \multirow[t]{3}{*}{ Other de novo } & Generic semi & 0.732 & {$[0.748]$} & 1.122 & {$[0.780]$} \\
\hline & Specific semi & 2.325 & {$[0.794] * * *$} & 2.048 & {$[0.842]^{* *}$} \\
\hline & Other semi & Ref & Ref & Ref & Ref \\
\hline Fully acquired & & 1.342 & {$[0.620]$} & 0.994 & {$[0.640]$} \\
\hline Fabless & & 0.509 & {$[0.385]$} & 0.331 & {$[0.414]$} \\
\hline $\mathrm{PhD}$ & & -0.526 & {$[0.356]$} & -0.389 & {$[0.392]$} \\
\hline Serial entrepreneur & & 0.046 & {$[0.418]$} & 0.024 & {$[0.435]$} \\
\hline Founding team & & -0.199 & {$[0.413]$} & -0.562 & {$[0.425]$} \\
\hline Patent & & 0.290 & {$[0.343]$} & 0.118 & {$[0.363]$} \\
\hline Size (Ln) & & -2.049 & {$[0.803]^{* *}$} & -1.407 & {$[0.811]^{*}$} \\
\hline Size sq (Ln) & & 0.460 & {$[0.145]^{* * *}$} & 0.281 & {$[0.149]^{*}$} \\
\hline Constant & & 1.009 & {$[1.530]$} & 0.879 & {$[1.564]$} \\
\hline \# of observations & & 395 & & & \\
\hline Log-pseudolikelihood & & -338.516 & & & \\
\hline Chisq & & $146.507 * * *$ & & & \\
\hline Pseudo Rsq & & 0.1359 & & & \\
\hline
\end{tabular}

Standard errors adjusted for clustering at firm level in brackets

$* * * * * * *$ Significance at $1 \%, 5 \%$ and $10 \%$ level respectively. All specifications include a full vector of country, entry year and exit year dummies. Other Buyers is the omitted category

Columns (1) and (2) report the regression coefficients for those startups that have been acquired by Semiconductor buyers and User industry buyers respectively. The reference category is 'Other buyers'.

In column (1) the coefficient estimate of focal spinouts producing generic products is positive and significant indicating that these firms are likely to be acquired by semiconductor buyers. The coefficient is also positive and significant in column (2), indicating that focal spinouts are also likely to be acquired by user buyers. These results are in line with $\mathrm{H} 1$.

The coefficient estimates of user-industry spinouts producing specific products is positive and significant in columns (1) and (2). These results are consistent with $\mathrm{H} 2$ as they indicate that spinouts from a focal industry that produce marketspecific products are likely to be acquired by buyer firms in both the focal industry and in user-industries. The coefficient estimates of user-industry spinouts producing 
Table 6 Marginal effects for acquisition by categories of buyers

\begin{tabular}{llll}
\hline & & Semiconductor buyer & User buyer \\
\hline Type of startup & Interaction & M. Effect & M. Effect \\
Focal spinout & Generic semi & 0.1819715 & 0.0415166 \\
& Specific semi & 0.0897535 & 0.100831 \\
User-industry spinout & Generic semi & 0.1353809 & 0.0033491 \\
& Specific semi & 0.0871673 & 0.0480197 \\
\hline
\end{tabular}

The table reports the marginal effects computed for each variable of interest. The marginal effects were computed as discrete change, holding all other independent variables constant at their mean value if they were dichotomous or at their median values if they were continuous. With regard to the marginal effects for our heritage knowledge dummies, we computed the discrete change from belonging to the reference category of "other de-novo in other semi" to being a focal spinout (in generic or specific) or a user-industry spinout (in generic or specific), respectively

generic products is not significant, suggesting that these firms are not more (or less) likely than other de-novo firms to be acquired by either firms in the focal industry or by firms in user industries. This result is in line with $\mathrm{H} 3$.

Concerning our control variables, we find a non-linear relationship between firm size and the probability of being acquired by both semiconductor and user buyers. None of the remaining control variables is significant. Although this result might seem surprising, it should not be taken as an indication that the characteristics of the founders (as measured by serial entrepreneur) or firm quality (as measured by patents) do not affect acquisition. Both of them are important drivers of acquisition, but they do not seem relevant to discriminate between types of buyers.

To better understand the implications of our estimations we need to bear in mind that the estimated coefficients in Table 5, when exponentiated, represent the relative probabilities for a specific category of start-up to be acquired by a certain type of buyer with respect to the reference category (i.e. 'other buyers'). We can assess and compare the overall probability, instead of the relative probability, by computing the marginal effects. These results are summarized in Table $6 .^{9}$

The probability to be acquired by semiconductors firms is about $18 \%$ points higher for focal spinouts producing generic products (than for other de-novo startups producing 'other semiconductors'); $9 \%$ points higher for focal spinouts producing market-specific products; $13.5 \%$ points higher for user-industry spinouts producing generic products, and $8.7 \%$ points higher for user-industry spinouts producing market-specific products. The probability to be acquired by a user buyer is about $4 \%$ points higher for focal spinouts producing generic products, $10 \%$ points higher for focal spinouts producing market-specific products, $0.3 \%$ points higher for userindustry spinouts producing generic products (albeit the estimated coefficient in this

\footnotetext{
9 The marginal effects were computed as discrete change, holding all other independent variables constant at their mean value if they were dichotomous or at their median values if they were continuous. The marginal effects of the heritage knowledge dummies were computed as discrete change from belonging to the reference category of "other de-novo in other semi" to being a focal spinout (in generic or specific) or a user-industry spinout (in generic or specific), respectively.
} 


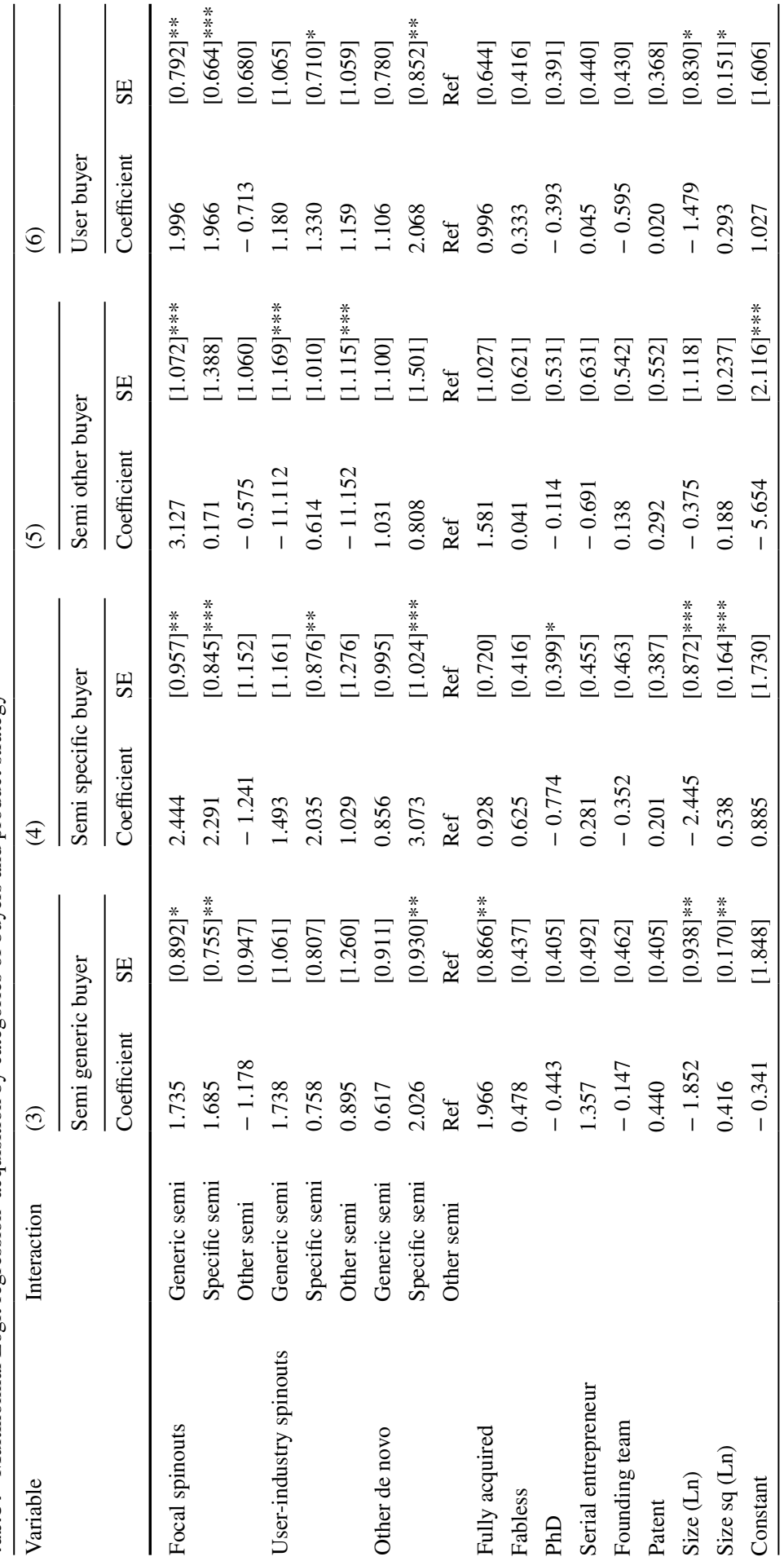




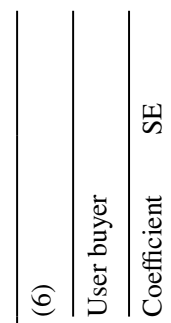

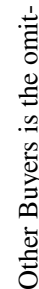

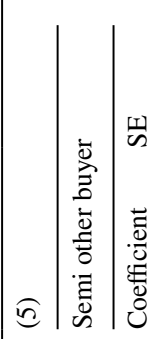

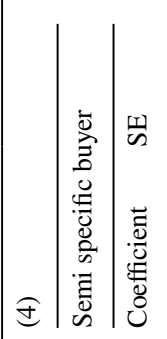

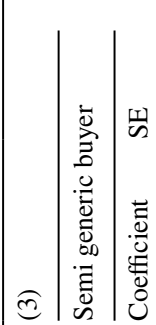
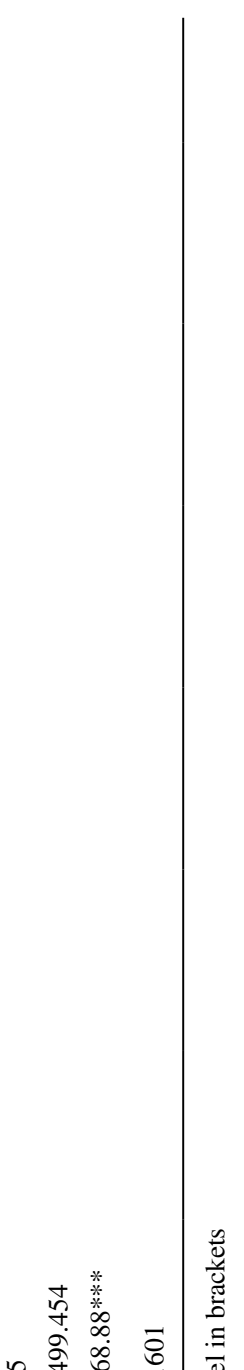

离

永

ซี

$\stackrel{2}{2}$

产

言

¿

范

亚

$\underset{\sigma}{2}$

을

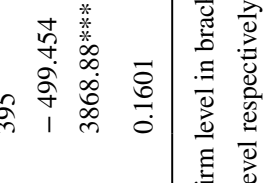

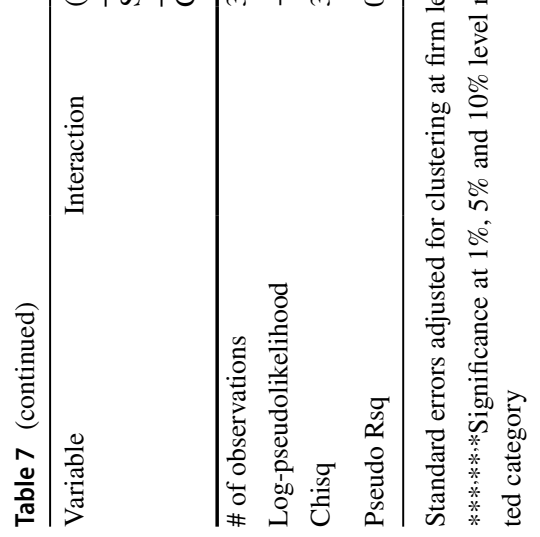


case is not statistically significant from zero), and $4.8 \%$ points higher for user-industry spinouts producing market-specific products.

To test the remaining hypotheses we need to account explicitly for the product strategy of the buyer firms. We do this in Table 7 where we distinguish four types of buyers: Semiconductor buyers producing generic products (column 3), Semiconductor buyers producing market specific products (column 4), Semiconductor buyers producing other products (column 5), and User buyers (column 6). As in the previous case, the reference category is 'Other buyers'.

Accounting for the product strategy of the buyer allows us to highlight similarities and differences with respect to the prior analysis. On the one hand, the coefficient estimates of focal spinouts producing generic and specific products is still positive and significant in columns (3), (4) and (6), indicating that these firms are likely to be acquired by all types of 'Semiconductor buyers' as well as by 'User buyers'. By contrast, the coefficient estimates for user-industry spinouts producing specific products are not significant in column (3), but positive and significant in columns (4) and (6). This finding suggests that spinouts from user industries that produce market-specific products are not likely to be acquired by buyer firms in the focal industry that produce generic products. This is consistent with H4a. It also indicates that spinouts from user industries that produce market-specific products are likely to be acquired by buyer firms in the focal industry that produce market specific products and by buyer firms in user industries. Both results provide support for H4b. In particular, the computed marginal effects for these two cases indicate that the probability to be acquired by a buyer in the focal industry that produces market specific products is about $20 \%$ points higher for a user-industry spinout producing marketspecific products (than for other startups producing other semiconductors). For the same category of firms, the probability to be acquired by a user-industry buyer is $3.7 \%$ points higher.

Overall, our empirical analysis provides two sets of results. First, we find evidence that the knowledge heritage of spinouts influences their probability to be acquired by different types of buyers. Second, we find evidence that product strategy plays a role particularly for the acquisition of spinouts that enter the focal industry from downstream industries. Indeed, only user-industry spinouts that produce market-specific products are likely to be acquired, and their buyers are limited to firms that are active in market-specific product categories.

Additional analysis is conducted to check for possible biases in our results. Our analysis considers the case of a firm (the target) that must choose among a set of potential buyers. It might be argued, however, that the choice of the buyer is indeed consequential to the choice of being acquired versus remaining an independent entity. If this is the case, then failing to account explicitly for this possibility would introduce a sample selection bias in our results. To overcome this potential problem we re-estimate our model using a two-step procedure similar to Heckman (1979). Specifically, we first estimate a binary Logit model on the overall sample of 936 semiconductor firms. The dependent variable in this case is equal to one if the firm 
Table 8 Robustness check-multinomial Logit regression-acquisition by categories of buyers (second stage Heckman selection model)

\begin{tabular}{|c|c|c|c|c|c|}
\hline \multirow[t]{3}{*}{ Variable } & \multirow[t]{3}{*}{ Interaction } & \multicolumn{2}{|l|}{ (7) } & \multicolumn{2}{|l|}{ (8) } \\
\hline & & \multicolumn{2}{|l|}{ Semi buyer } & \multicolumn{2}{|l|}{ User buyer } \\
\hline & & Coefficient & SE & Coefficient & SE \\
\hline \multirow[t]{3}{*}{ Focal spinout } & Generic semi & 2.391 & {$[0.789] * * *$} & 2.001 & {$[0.799]^{* *}$} \\
\hline & Specific semi & 1.848 & {$[0.648] * * *$} & 1.925 & {$[0.674]^{* * *}$} \\
\hline & Other semi & -1.037 & {$[0.731]$} & -0.718 & {$[0.683]$} \\
\hline \multirow[t]{3}{*}{ User-industry spinout } & Generic semi & 1.475 & {$[0.954]$} & 1.180 & [1.071] \\
\hline & Specific semi & 1.360 & {$[0.670]^{* * *}$} & 1.304 & {$[0.710]^{*}$} \\
\hline & Other semi & 0.853 & {$[1.108]$} & 1.122 & {$[1.081]$} \\
\hline \multirow[t]{3}{*}{ Other de novo } & Generic semi & 0.774 & {$[0.748]$} & 1.055 & {$[0.779]$} \\
\hline & Specific semi & 2.367 & {$[0.792]^{* * *}$} & 2.000 & {$[0.835]^{* *}$} \\
\hline & Other semi & Ref & Ref & Ref & Ref \\
\hline Fully acquired & & 1.387 & {$[0.627] * *$} & 0.963 & {$[0.640]$} \\
\hline Fabless & & 1.024 & {$[0.482] * *$} & 0.242 & {$[0.511]$} \\
\hline $\mathrm{PhD}$ & & -0.749 & {$[0.371]^{* *}$} & -0.339 & [0.399] \\
\hline Serial entrepreneur & & 0.184 & {$[0.427]$} & 0.019 & {$[0.444]$} \\
\hline Founding team & & 0.626 & {$[0.622]$} & -0.710 & [0.649] \\
\hline Patent & & 0.744 & {$[0.414]^{*}$} & -0.053 & {$[0.426]$} \\
\hline Size (Ln) & & -2.932 & {$[1.044]^{* * *}$} & -1.230 & {$[1.055]$} \\
\hline Size sq (Ln) & & 0.697 & {$[0.208]^{* * *}$} & 0.236 & {$[0.209]$} \\
\hline Inverse Mills' ratio & & 5.206 & {$[2.541]^{* *}$} & -0.758 & [2.699] \\
\hline Constant & & -2.922 & [2.339] & 1.479 & [2.429] \\
\hline \# of observations & & 395 & & & \\
\hline Log-pseudolikelihood & & -335.709 & & & \\
\hline Chisq & & $333.05 * * *$ & & & \\
\hline Pseudo Rsq & & 0.1431 & & & \\
\hline
\end{tabular}

Standard errors adjusted for clustering at firm level in brackets

$* * *, * * *$ Significance at $1 \%, 5 \%$ and $10 \%$ level respectively. All specifications include a full vector of country, entry year and exit year dummies. Other Buyers is the omitted category

has been acquired and zero otherwise. ${ }^{10}$ We then use the residuals from the first stage regression to compute inverse Mills' ratios that are added as covariates in the multinomial regression in the second stage. The results of the second stage estimations are reported in Tables 8 and 9.

\footnotetext{
${ }^{10}$ The specification used in the first stage of the estimation is similar to Model (2) from Table 6 in Adams et al. (2016). It includes as covariates the same variables employed in the second stage (Firm origin, Fabless, Serial entrepreneur, Founding team, Patent, Size (Logarithm) and Size sq (Logarithm)). In addition to these it includes also a dummy for venture capital support which is used as exclusion restriction. The estimated coefficient of this variable is positive and significant.
} 


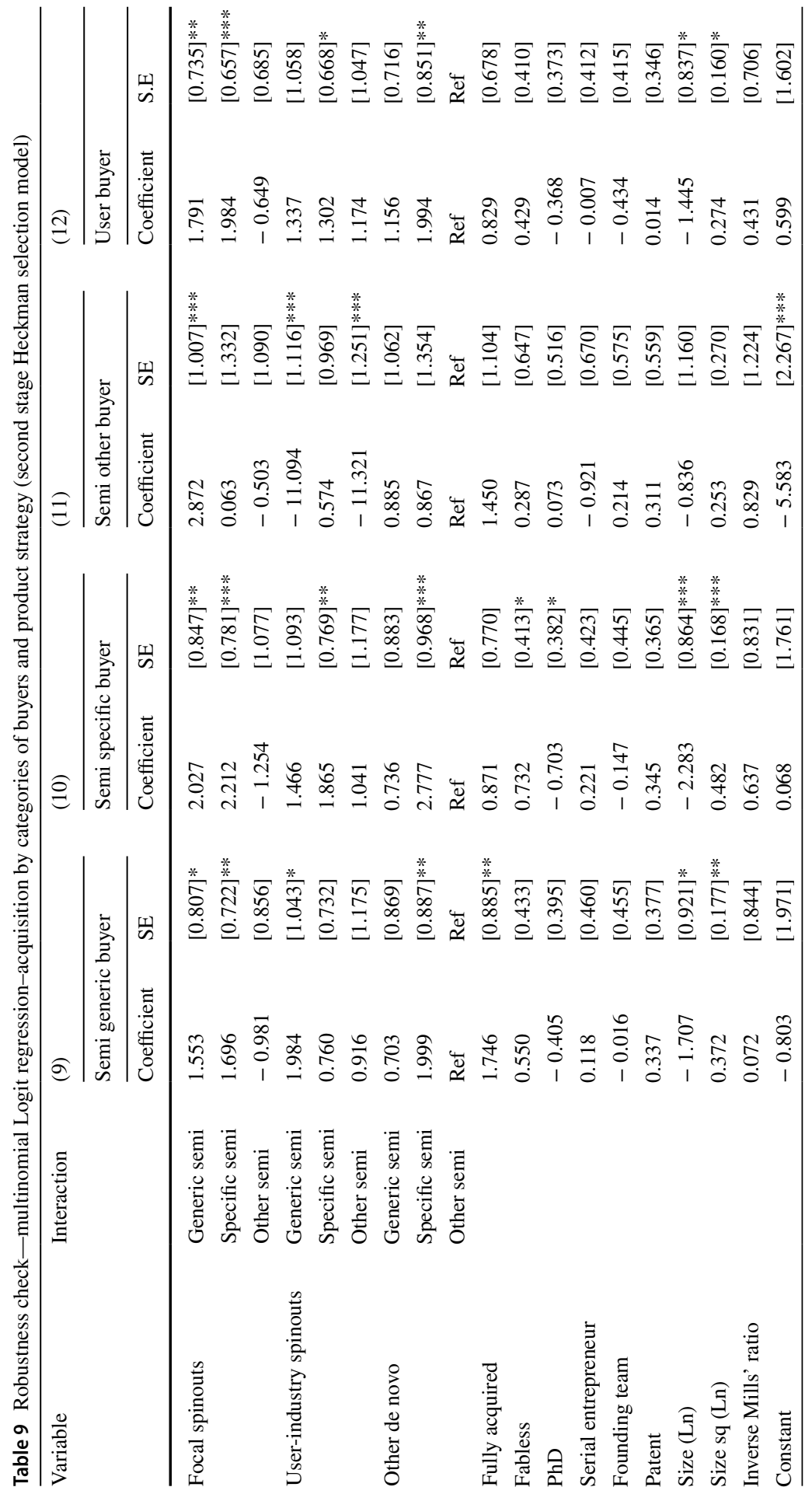




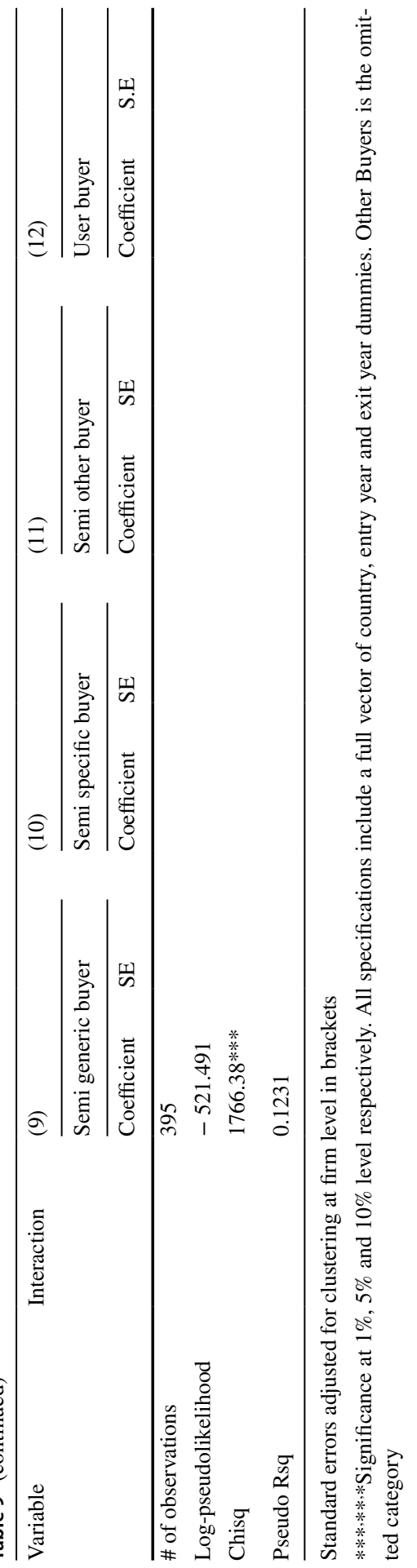


A comparison between these results and those of our primary analysis indicates that, in the case of acquisitions by categories of buyers (compare with Table 5), the sign and the statistical significance of the coefficients capturing the interaction between firm origin and product strategy is maintained for both semi buyer and user buyer. The magnitude of the estimated coefficients is slightly higher than in our baseline regressions. Also, when we account for the product strategy of buyers (compare with Table 7) the sign and the statistical significance of the coefficients is maintained. However, in this case, the coefficients are lower than in the baseline regression. It may be noted that the estimated coefficient of the inverse Mills' ratio is positive and statistically significant only in model (7) in Table 8, indicating that sample selection bias is a potential problem only for semiconductor buyers. To check whether this result might be the consequence of unadjusted standard errors due to the fact that our estimation procedure deviates from the traditional (i.e. linear) two-stage model, we reran the estimation presented in Table 8 via bootstrapping. Results of these further regressions produced non-significant coefficients for the inverse Mills' ratio that suggest that selection bias is not a concern in our data. ${ }^{11}$

\section{Discussion and conclusions}

Entrepreneurial spinouts have become a popular target for buyers in high technology industries. Spinouts are characterized by a unique set of resources and capabilities that distinguish them from both established firms and other types of startup ventures. Yet to date, we are not aware of any study that focuses explicitly on spinouts as acquisition targets or on how the resource endowments of spinout ventures might affect their potential to be acquired. Our research breaks new ground by beginning to explore these issues. We characterize the profiles of spinouts in terms of the knowledge context from which their founders originate and their product strategies at entry. We then examine how such profiles may be evaluated by different types of buyer firms according to their industry context and their product focus. We find that spinouts from firms in the focal industry are appealing targets for a broad range of buyer firms both from within the focal industry and from related, downstream industries, independent of their product strategy at entry. Spinouts from downstream, user industries that enter into the focal industry, on the other hand, tend to appeal to a more limited buyer base. Our findings also show that the appeal of spinouts from user-industries depends on their product strategy at entry: only those that apply their knowledge of downstream needs and applications to produce market-specific products, tend to appeal to potential buyers in both the focal and downstream industries.

This study contributes to scholarship in entrepreneurship and in evolutionary theory that examines how the knowledge context from which entrepreneurs emerge shapes the character of the new firms they create (Agarwal \& Shah, 2014; Helfat \& Lieberman, 2002; Nelson \& Winter, 1982). Extant work on new ventures shows that spinouts have a higher likelihood of survival than other de novo startups (Helfat \&

11 These results are reported in Table 11 in the Appendix. 
Lieberman, 2002; Klepper \& Sleeper, 2005) due to the knowledge resources inherited through their founders from their pre-entry experience in an incumbent firm (Agarwal et al., 2004). Research also shows that the knowledge resources inherited by spinouts with origins in a downstream industry may support their entry and survival in a new, focal industry (Adams et al., 2019). Similar to spinouts from the focal industry, in fact, spinouts from user industries are shown to have a higher likelihood to survive than other de novo startups, which are generally characterized by a lack of pre-entry experience in an industry context (Adams et al., 2016). The current study extends this work to show that the knowledge resources inherited by spinout ventures affect not only their ability to enter and survive in an industry, but also their potential to be acquired and by whom. Consistent with previous studies, our work suggests that the effects of the initial endowment of resources and capabilities that spinouts inherit persist over time, beyond their success at entry and their performance in the focal industry, to frame even their options for exit if they chose to sell their ventures (Chen et al., 2012; Helfat \& Lieberman, 2002). Our findings show, in fact, that the knowledge context from which spinouts originate shape their potential for acquisition by different types of buyer firms. Even further, our work suggests that the potential for acquisition is affected by the degree of similarity between the resource characteristics of the buyer firm and the pre-entry resources and capabilities of the spinout venture. A match between market needs and resources seems to play a fundamental role in motivating the acquisition of spinouts, especially for those ventures that cross industry boundaries.

By examining the knowledge context from which spinouts originate, this study also contributes to the literature on acquisition motivation. Research on acquisitions commonly acknowledges that one of the main reasons that buyers acquire technology firms is to gain the knowledge and capabilities embedded in the individuals and teams within the target organizations. In the case of new startups, moreover, buyer firms view acquisitions as a way to harness the innovative power of young, entrepreneurial ventures. Yet given the challenges of collecting information about the specific profiles of entrepreneurs and their teams, and of assessing knowledge resources from these profiles, research on such processes is limited. We propose that identifying the context of the entrepreneurial origin of founders may provide a complementary approach (Carroll et al., 1996; Klepper and Simons, 2000). Such an approach relies on indirect rather than direct measures of knowledge. However, it allows the opportunity to do longitudinal studies to track genealogical relationships between firms and across industries. Consistent with previous studies of spinouts (Adams et al., 2016, 2019; Agarwal et al., 2004; Chatterji, 2009; Klepper, 2009), our findings suggest that understanding the knowledge context from which new and independent ventures originate provides a good indication of the knowledge endowments that founders bring into their new organizations, and of the kinds of technologies, products, applications and markets with which they have had experience. This information may then be used to assess the potential motivation of buyers to acquire such ventures. In our study, we use this approach to examine the knowledge endowments of spinout ventures from both a focal industry and a related, user industry. But a similar methodology may also be used to examine the acquisition of spinouts from other knowledge contexts such as supplier industries or universities. The extant 
literature on the sources of innovative new ventures identifies such contexts as distinct arenas in which individuals develop informational advantages that provide a basis for the creation of new firms (Adams et al., 2019; Agarwal \& Shah, 2014). Our study suggests that these distinctions may also be useful for understanding the appeal of different types of startups to potential buyers.

This study also opens up an interesting research question concerning industrial dynamics. The acquisition of focal and user-industry spinouts by firms operating in the focal industry does not modify the type of firms active in the industry. Rather such acquisitions work to increase the market share, augment the market power or extend the product lines and technological capabilities of the buyer firms in the focal industry. By contrast, the acquisition of spinouts by user firms examined in this paper result in changes in the roster of participants in the focal and downstream industries. User firms that acquire spinouts in the focal industry de facto vertically integrate into the focal industry, thus expanding their activities in a related industry. As a consequence, the nature of the competitive process changes and new patterns of vertical firm structure emerge in the focal and downstream industries. More research is needed to understand how such dynamics may affect the evolution of vertical firm structure over time in both the focal industry and the related downstream industries (Helfat, 2015).

For managers and investors, this study also offers important insights concerning knowledge transfer through acquisitions. Managers have traditionally looked to mechanisms such as personnel mobility, collaborative activities with users, strategic alliances, and networks to access the knowledge of user firms in downstream industries. This study suggests that the acquisition of spinout firms whose founders originate from related, downstream contexts may offer an additional path to access such knowledge. Coherent with other studies on the knowledge inheritance of spinouts (Agarwal et al., 2004; Klepper, 2009), this study suggests that the resources and capabilities that are acquired through the acquisition of spinouts are often linked closely to the founders of such startups, at least during their first years of existence. Much of the knowledge that is inherited through the founders may be tacit in nature, 'sticky' to individuals, or embedded in teams and routines. As a result, acquiring firms will need to consider carefully how to handle the position and contributions of the founders and founding teams post-acquisition in their negotiations in order to assure an effective transfer of such resources. Such considerations should also be part of the due diligence process that precedes the acquisition of a spinout. 
It is important to note the limitations of our study. Given that this work represents an initial investigation into spinout acquisitions, each of these limitations also raises interesting questions for future research. Although the semiconductor industry provides a rich environment in which to study the relationship between the knowledge endowment of new ventures and acquisitions, our empirical study of a single industry limits the generalizability of our findings. We suspect, however, that similar patterns will be observed in other high-technology industries that are characterized by heterogeneous downstream markets and by technological knowledge that is not easily codified and therefore not available through markets for technology (Arora et al., 2004). Therefore, industries such as lasers, hard disks, robotics and software offer fertile ground for future research.

Our definition of user industries is wide and, with the current dataset, we are unable to match the specific industry of origin of user-industry spinouts (e.g. telecommunications, consumer electronics, automobile, etc.) with the industries of specific downstream buyers or with specific product segments. Since scholarship indicates that spinouts tend to enter product categories close to their industry of origin, further research is needed to understand how this relationship might affect acquisition decisions. Similarly, we have used a simple binary classification to identify the main product groups of firms in our sample. Future studies may go further to examine the specific product lines and $R \& D$ investments of these firms to gain a better understanding of the extent to which the selection criteria of buyer firms is driven by the motivation to obtain specific products and technologies from the spinout or by the goal to secure the knowledge resources embedded in the people within the organization.

\section{Appendix}

See Tables 10 and 11. 


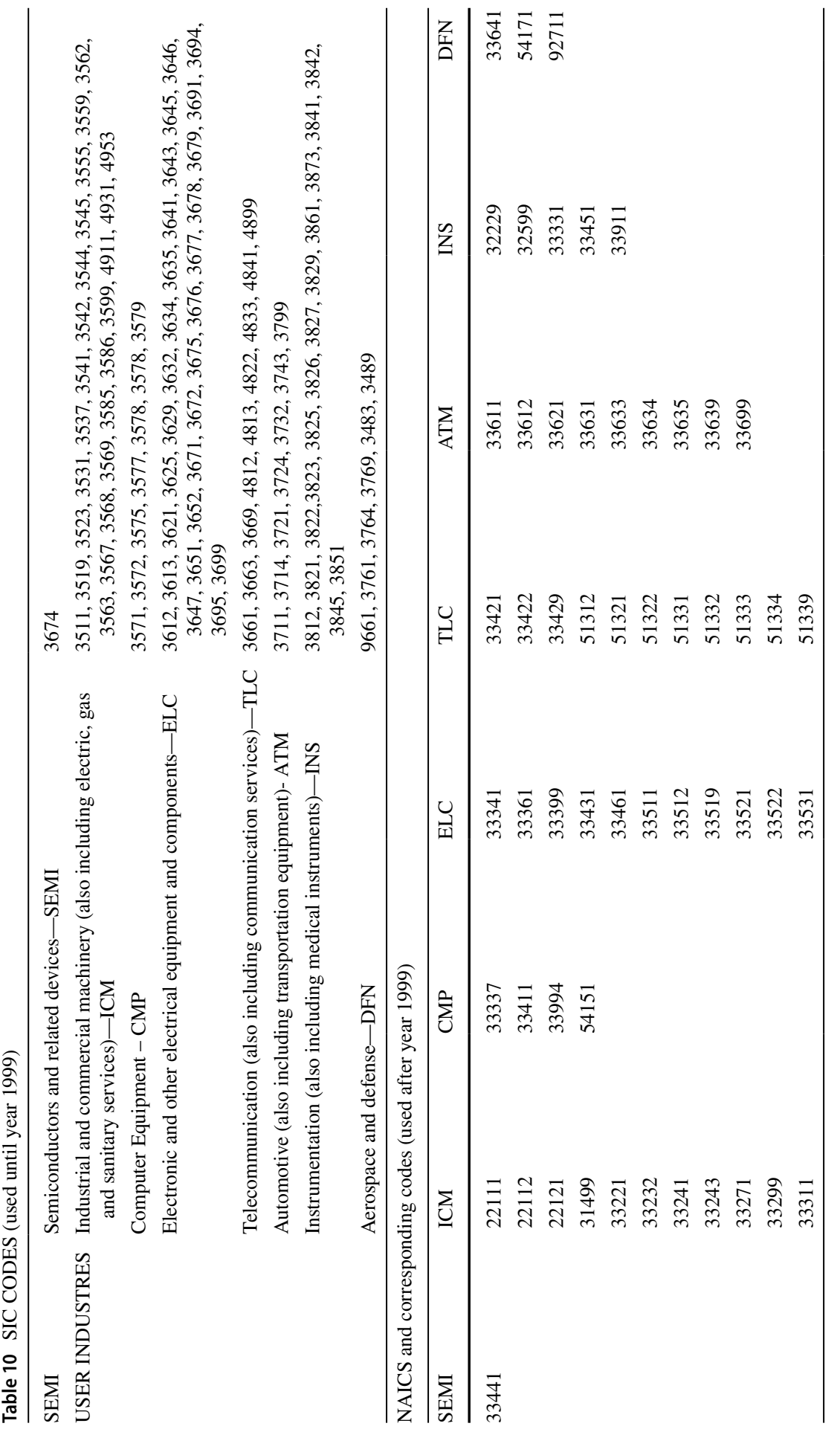




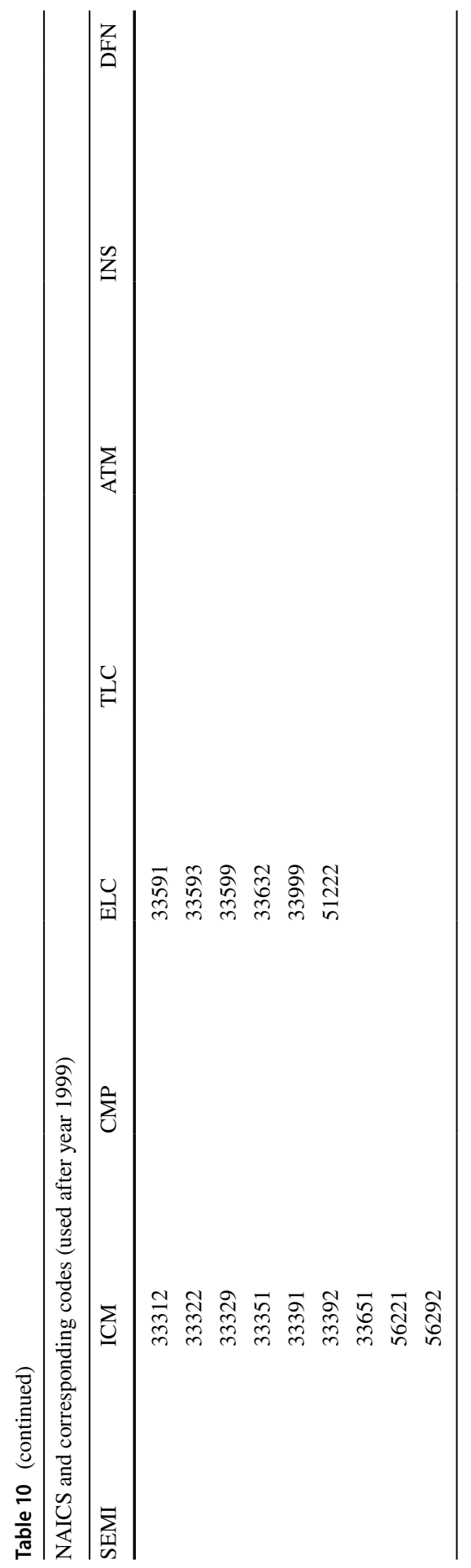


Table 11 Robustness check-multinomial Logit regression-acquisition by categories of buyers (second stage Heckman selection model with bootstrapped SE)

\begin{tabular}{|c|c|c|c|c|c|}
\hline \multirow[t]{3}{*}{ Variable } & \multirow[t]{3}{*}{ Interaction } & \multicolumn{2}{|l|}{ (7) } & \multicolumn{2}{|l|}{ (8) } \\
\hline & & \multicolumn{2}{|l|}{$\underline{\text { Semi buyer }}$} & \multicolumn{2}{|l|}{ User buyer } \\
\hline & & Coefficient & SE & Coefficient & $\mathrm{SE}$ \\
\hline \multirow[t]{3}{*}{ Focal spinout } & Generic semi & 2.391 & {$[1.002]^{* *}$} & 2.001 & {$[1.062]^{*}$} \\
\hline & Specific semi & 1.848 & {$[0.805]^{* *}$} & 1.925 & {$[0.907]^{* *}$} \\
\hline & Other semi & -1.037 & {$[0.964]$} & -0.718 & {$[0.884]$} \\
\hline \multirow[t]{3}{*}{ User-industry spinout } & Generic semi & 1.475 & {$[5.604]$} & 1.180 & {$[5.772]$} \\
\hline & Specific semi & 1.360 & {$[0.771]^{*}$} & 1.304 & {$[0.734]^{*}$} \\
\hline & Other semi & 0.853 & {$[5.608]$} & 1.122 & {$[5.805]$} \\
\hline \multirow[t]{3}{*}{ Other de novo } & Generic semi & 0.774 & [0.891] & 1.055 & [1.009] \\
\hline & Specific semi & 2.367 & {$[1.108]^{* *}$} & 2.000 & [3.173] \\
\hline & Other semi & Ref & Ref & Ref & Ref \\
\hline Fully acquired & & 1.387 & {$[1.631]$} & 0.963 & [1.628] \\
\hline Fabless & & 1.024 & [2.194] & 0.242 & [2.277] \\
\hline $\mathrm{PhD}$ & & -0.749 & [1.091] & -0.339 & [1.129] \\
\hline Serial entrepreneur & & 0.184 & [0.804] & 0.019 & {$[0.883]$} \\
\hline Founding team & & 0.626 & {$[3.342]$} & -0.710 & [3.473] \\
\hline Patent & & 0.744 & {$[1.962$} & -0.053 & [1.997] \\
\hline Size (Ln) & & -2.932 & {$[14.662]$} & -1.230 & [14.742] \\
\hline Size sq (Ln) & & 0.697 & {$[2.597]$} & 0.236 & {$[2.629]$} \\
\hline Inverse Mills' ratio & & 5.206 & {$[20.860]$} & -0.758 & [21.695] \\
\hline Constant & & -2.922 & {$[6.055]$} & 1.479 & {$[6.338]$} \\
\hline \# of observations & & 395 & & & \\
\hline Log-pseudolikelihood & & -335.709 & & & \\
\hline Chisq & & $333.05 * * *$ & & & \\
\hline Pseudo Rsq & & 0.1431 & & & \\
\hline
\end{tabular}

Bootstrapped standard errors adjusted for clustering at firm level in brackets

$* * * * * * *$ Significance at $1 \%, 5 \%$ and $10 \%$ level respectively. All specifications include a full vector of country, entry year and exit year dummies. Other Buyers is the omitted category

\section{Further explorative analysis}

Further analyses were conducted to assess the sensitivity of our results to changes in the composition of the sample of buyer firms. ${ }^{12}$

We started by observing that the distribution of buyer firms in our sample is slightly skewed, with the top 10 buyers in terms of number of acquired firms accounting for one fifth of total acquisitions. Skewness is higher within the subsamples, with the top five semiconductor buyers accounting for one third of the acquisitions made by semiconductor firms and the top five user buyers accounting for one fourth of the acquisitions made by users. If results were driven by some characteristics of the buyers rather than by the knowledge heritage and/or product strategy of the target firms, we would expect our findings to change depending on the presence

\footnotetext{
12 Results of these estimations are not shown here for reason of space. They are available upon request from the authors.
} 
or absence of the top buyers. To control for this possibility, we remove the top 5 semiconductor and user buyers and re-estimate our models for these sub-samples. The main results remained unchanged. ${ }^{13}$

In addition, we considered the possibility that our results might be explained by the overall value of the deals above and beyond the number of acquisitions themselves. If some types of buyers are more likely than other to pursue expensive deals, then our evidence that the knowledge heritage of spinouts as well as their product strategy influences their probability to be acquired by different types of buyers may change depending on the propensity of the buyer to pay. To explore this possibility, we computed the mean value of the deals and split the sample into two subsets (equal or above and below the mean) and rerun our regressions on these subsamples. While the analysis of the subsample of 'below the mean' acquisitions generally confirmed our main results, the analysis of the subsample of 'equal or above the mean' acquisitions revealed some interesting divergence from our main results. In particular, only firms that produce market-specific products were likely to be acquired, and their buyers are limited to user firms or semiconductor firms that are active in market-specific product categories. This result departs from $\mathrm{H} 1$ as spinouts from the focal industry that produce generic products are no longer likely to be acquired by all types of firms in the focal industry. We do not think that this result indicates that acquisitions of focal spinouts producing generic products are not important. Rather we interpret this result as an indication that acquisitions of user-industry spinouts that produce market-specific products are relatively more valuable. This is consistent with the idea that buyers are willing to pay a price premium for acquiring knowledge that is tacit, defies articulation and cannot be accessed in any other way.

Finally, we explored whether the identity of the buyer, rather than the number or the value of the acquisition, may affect our results. Semiconductor leaders such as Intel or Broadcom are active buyers as they pursue acquisitions of young startups. Similarly, notable user buyers (i.e., Cisco Systems) also pursue growth strategies based on acquisitions both within their own industry and across industry boundaries. To check whether the presence of these 'very active' buyers affects our results we remove them from the sample and rerun our regression. Results from these additional regressions were generally consistent with our main hypotheses.

Open Access This article is licensed under a Creative Commons Attribution 4.0 International License, which permits use, sharing, adaptation, distribution and reproduction in any medium or format, as long as you give appropriate credit to the original author(s) and the source, provide a link to the Creative Commons licence, and indicate if changes were made. The images or other third party material in this article are included in the article's Creative Commons licence, unless indicated otherwise in a credit line to the material. If material is not included in the article's Creative Commons licence and your intended use is not permitted by statutory regulation or exceeds the permitted use, you will need to obtain permission directly from the copyright holder. To view a copy of this licence, visit http://creativecommons.org/licen ses/by/4.0/.

\footnotetext{
${ }^{13}$ We have also removed both the top 5 semiconductor buyers and the top 5 user buyers at the same time. Again the main results did not change.
} 


\section{References}

Adams, P., Fontana, R., \& Malerba, F. (2013). The magnitude of innovation by demand in a sectoral system: The role of industrial users in semiconductors. Research Policy, 42(1), 1-14.

Adams, P., Fontana, R., \& Malerba, F. (2016). User-industry spinouts: Downstream industry knowledge as a source of new firm entry and survival. Organization Science, 27(1), 18-35.

Adams, P., Fontana, R., \& Malerba, F. (2017). Bridging knowledge resources: The location choices of spinout. Strategic Entrepreneurship Journal, 11(2), 93-121.

Adams, P., Fontana, R., \& Malerba, F. (2019). Linking vertically related industries: Entry by employee spinouts across industry boundaries. Industrial and Corporate Change, 28(3), 529-550.

Agarwal, R., Echambadi, R., Franco, A. M., \& Sarkar, M. B. (2004). Knowledge transfer through inheritance: Spin-out generation, development, and survival. Academy of Management Journal, 47(4), 501-522.

Agarwal, R., \& Shah, S. K. (2014). Knowledge sources of entrepreneurship: Firm formation by academic, user and employee innovators. Research Policy, 43(7), 1109-1133.

Ahuja, G., \& Katila, R. (2001). Technological acquisitions and the innovation performance of acquiring firms: A longitudinal study. Strategic Management Journal, 22(3), 197-220.

Andersson, M., \& Xiao, J. (2016). Acquisitions of start-ups by incumbent businesses: A market selection process of "high-quality" entrants? Research Policy, 45(1), 272-290.

Arora, A., Fosfuri, A., \& Gambardella, A. (2001). Markets for technology and their implications for corporate strategy. Industrial and Corporate Change, 10(2), 419-451.

Arora, A., Fosfuri, A., \& Gambardella, A. (2004). Markets for technology: The economics of innovation and corporate strategy. MIT Press.

Arora, A., \& Gambardella, A. (2010). Ideas for rent: An overview of markets for technology. Industrial and Corporate Change, 19(3), 775-803.

Arora, A., \& Nandkumar, A. (2011). Cash-out or flameout! Opportunity cost and entrepreneurial strategy: Theory, and evidence from the information security industry. Management Science, 57(10), 1844-1860.

Barney, J. (1991). Firm resources and sustained competitive advantage. Journal of Management, 17(1), 99-120.

Benson, D., \& Ziedonis, R. H. (2009). Corporate venture capital as a window on new technologies: Implications for the performance of corporate investors when acquiring startups. Organization Science, 20(2), 329-351.

Brittain, J. W., \& Freeman, J. (1986). Entrepreneurship in the semiconductor industry. In The annual meeting of the Academy of Management, Dallas.

Brown, C., \& Linden, G. (2011). Chips and change: How crisis reshapes the semiconductor industry. MIT Press.

Brüderl, J., Preisendörfer, P., \& Ziegler, R. (1992). Survival chances of newly founded business organizations. American Sociological Review, 57, 227-242.

Buenstorf, G. (2007). Evolution on the shoulders of giants: Entrepreneurship and firm survival in the German laser industry. Review of Industrial Organization, 30(3), 179-202.

Capron, L., \& Mitchell, W. (2009). Selection capability: How capability gaps and internal social frictions affect internal and external strategic renewal. Organization Science, 20(2), 294-312.

Carpenter, R. E., \& Petersen, B. C. (2002). Capital market imperfections, high-tech investment, and new equity financing. The Economic Journal, 112(477), 54-72.

Carroll, G. R., Bigelow, L. S., Seidel, M. D. L., \& Tsai, L. B. (1996). The fates of de novo and de alio producers in the American automobile industry 1885-1981. Strategic Management Journal, 17(S1), 117-137.

Chatterji, A. K. (2009). Spawned with a silver spoon? Entrepreneurial performance and innovation in the medical device industry. Strategic Management Journal, 30(2), 185-206.

Chatterji, A. K., \& Fabrizio, K. (2012). How do product users influence corporate invention. Organization Science, 23(4), 971-987.

Chatterji, A. K., \& Fabrizio, K. R. (2014). Using users: When does external knowledge enhance corporate product innovation? Strategic Management Journal, 35(10), 1427-1445.

Chen, P. L., Williams, C., \& Agarwal, R. (2012). Growing pains: Pre-entry experience and the challenge of transition to incumbency. Strategic Management Journal, 33(3), 252-276.

Christensen, C. M. (1997). The Innovator's Dilemma. Harvard Business School Press. 
Clarysse, B., Wright, M., \& Van de Velde, E. (2011). Entrepreneurial origin, technological knowledge, and the growth of spin-off companies. Journal of Management Studies, 48(6), 1420-1442.

Cockburn, I. M., \& MacGarvie, M. J. (2011). Entry and patenting in the software industry. Management Science, 57(5), 915-933.

Colombo, M. G., \& Grilli, L. (2007). Funding gaps? Access to bank loans by high-tech start-ups. Small Business Economics, 29(1-2), 25-46.

Dencker, J. C., Gruber, M., \& Shah, S. K. (2009). Pre-entry knowledge, learning, and the survival of new firms. Organization Science, 20(3), 516-537.

DeTienne, D. R. (2010). Entrepreneurial exit as a critical component of the entrepreneurial process: Theoretical development. Journal of Business Venturing, 25(2), 203-215.

Dierickx, I., \& Cool, K. (1989). Asset stock accumulation and sustainability of competitive advantage. Management Science, 35(12), 1504-1511.

Dyer, J. H., Kale, P., \& Singh, H. (2004). When to ally and when to acquire. Harvard Business Review.

Eisenhardt, K. M., \& Martin, J. A. (2000). Dynamic capabilities: What are they? Strategic Management Journal, 21(10-11), 1105-1121.

Feldman, M., Feller, I., Bercovitz, J., \& Burton, R. (2002). Equity and the technology transfer strategies of American research universities. Management Science, 48(1), 105-121.

Feldman, M. P., Ozcan, S., \& Reichstein, T. (2019). Falling not far from the tree: Entrepreneurs and organizational heritage. Organization Science, 30(2), 337-360.

Fontana, R., \& Malerba, F. (2010). Demand as a source of entry and the survival of new semiconductor firms. Industrial and Corporate Change, 19(5), 1629-1654.

Franco, A. M., \& Filson, D. (2006). Spin-outs: Knowledge diffusion through employee mobility. The RAND Journal of Economics, 37(4), 841-860.

Frischmann, B.M. and M. J. Madison, K.J. Strandburg. (2014). Governing Knowledge Commons. Oxford University Press.

Graebner, M. E. (2004). Momentum and serendipity: How acquired leaders create value in the integration of technology firms. Strategic Management Journal, 25(8-9), 751-777.

Graebner, M. E., Eisenhardt, K. M., \& Roundy, P. T. (2010). Success and failure in technology acquisitions: Lessons for buyers and sellers. Academy of Management Perspectives, 24(3), 73-92.

Hall, B. H. (2002). The financing of research and development. Oxford Review of Economic Policy, $18(1), 35-51$.

Heckman, J. J. (1979). Statistical models for discrete panel data. University of Chicago.

Helfat, C. E. (2015). Vertical firm structure and industry evolution. Industrial and Corporate Change, 24(4), 803-818.

Helfat, C. E., \& Eisenhardt, K. M. (2004). Inter-temporal economies of scope, organizational modularity, and the dynamics of diversification. Strategic Management Journal, 25(13), 1217-1232.

Helfat, C. E., \& Lieberman, M. B. (2002). The birth of capabilities: Market entry and the importance of pre-history. Industrial and Corporate Change, 11(4), 725-760.

Higgins, M. C., \& Gulati, R. (2003). Getting off to a good start: The effects of upper echelon affiliations on underwriter prestige. Organization Science, 14(3), 244-263.

Holbrook, D., Cohen, W. M., Hounshell, D. A., \& Klepper, S. (2000). The nature, sources, and consequences of firm differences in the early history of the semiconductor industry. Strategic Management Journal, 21(10-11), 1017-1041.

Hsu, D. H., \& Ziedonis, R. H. (2013). Resources as dual sources of advantage: Implications for valuing entrepreneurial-firm patents. Strategic Management Journal, 34(7), 761-781.

Kapoor, R., \& Lim, K. (2007). The impact of acquisitions on the productivity of inventors at semiconductor firms: A synthesis of knowledge-based and incentive-based perspectives. Academy of Management Journal, 50(5), 1133-1155.

Karim, S., \& Mitchell, W. (2009). Path-dependent and path-breaking change: Reconfiguring business resources following acquisitions in the US medical sector: 1978-1995. Strategic Management Journal, 21, 1061-1081.

Kaul, A., \& Wu, B. (2016). A capabilities-based perspective on target selection in acquisitions. Strategic Management Journal, 37(7), 1220-1239.

Khessina, O. M., \& Carroll, G. R. (2008). Product demography of de novo and de alio firms in theoptical disk drive industry, 1983-1999. Organization Science, 19(1), 25-38.

Klepper, S. (2001). Employee startups in high-tech industries. Industrial and Corporate Change, 10(3), 639-674. 
Klepper, S. (2002). The capabilities of new firms and the evolution of the US automobile industry. Industrial and Corporate Change, 11(4), 645-666.

Klepper, S. (2009). Spinoffs: A review and synthesis. European Management Review, 6(3), 159-171.

Klepper, S., \& Simons, K. L. (2000). Dominance by birthright: Entry of prior radio producers and competitive ramifications in the US television receiver industry. Strategic Management Journal, 21(1011), 997-1016.

Klepper, S., \& Sleeper, S. (2005). Entry by spinoffs. Management Science, 51(8), 1291-1306.

Kogut, B., \& Zander, U. (1992). Knowledge of the firm, combinative capabilities, and the replication of technology. Organization Science, 3(3), 383-397.

McGrath, R. G., \& MacMillan, I. C. (2000). The entrepreneurial mindset: Strategies for continuously creating opportunity in an age of uncertainty (Vol. 284). Harvard Business Press.

Narver, J. C., \& Slater, S. F. (1990). The effect of a market orientation on business profitability. Journal of Marketing, 54(4), 20-35.

Nelson, R., \& Winter, S. (1982). An evolutionary theory of economic change. Harvard University Press.

Puranam, P., Singh, H., \& Zollo, M. (2003). A bird in the hand or two in the bush? Integration trade-offs in technology grafting acquisitions. European Management Journal, 21(2), 179-184.

Ranft, A. L., \& Lord, M. D. (2002). Acquiring new technologies and capabilities: A grounded model of acquisition implementation. Organization Science, 13(4), 420-441.

Roberts, E. B. (1991). Entrepreneurs in high technology: Lessons from MIT and beyond. Oxford University Press.

Saxenian, A. (1996). Regional advantage. Harvard University Press.

Shah, S., Winston Smith, S., \& Reedy, E. J. (2012). Who are user entrepreneurs? Findings on innovation, founder characteristics, and firm characteristics (The Kauffman Firm Survey). Findings on Innovation, Founder Characteristics, and Firm Characteristics (The Kauffman Firm Survey) (February 2012).

Shane, S. (2000). Prior knowledge and the discovery of entrepreneurial opportunities. Organization Science, 11(4), 448-469.

Shane, S. A. (2004). Academic entrepreneurship: University spinoffs and wealth creation. Edward Elgar Publishing.

Shane, S., \& Khurana, R. (2003). Bringing individuals back in: The effects of career experience on new firm founding. Industrial and Corporate Change, 12(3), 519-543.

Singh, H., \& Montgomery, C. A. (1987). Corporate acquisition strategies and economic performance. Strategic Management Journal, 8(4), 377-386.

Smith, S. W., \& Shah, S. K. (2013). Do innovative users generate more useful insights? An analysis of corporate venture capital investments in the medical device industry. Strategic Entrepreneurship Journal, 7(2), 151-167.

Sorenson, O., \& Audia, P. G. (2000). The social structure of entrepreneurial activity: Geographic concentration of footwear production in the United States, 1940-1989. American Journal of Sociology, $106(2), 424-462$.

Tanriverdi, H., \& Venkatraman, N. (2005). Knowledge relatedness and the performance of multibusiness firms. Strategic Management Journal, 26(2), 97-119.

Teece, D. J. (1986). Profiting from technological innovation: Implications for integration, collaboration, licensing and public policy. The Transfer and Licensing of Know-How and Intellectual Property: Understanding the Multinational Enterprise in the Modern World, 15, 67-88.

Teece, D. J., Pisano, G., \& Shuen, A. (1997). Dynamic capabilities and strategic management. Strategic Management Journal, 18(7), 509-533.

Tripsas, M. (2008). Customer preference discontinuities: A trigger for radical technological change. Managerial and Decision Economics, 29(2-3), 79-97.

Villalonga, B., \& McGahan, A. M. (2005). The choice among acquisitions, alliances, and divestitures. Strategic Management Journal, 26(13), 1183-1208.

Vohora, A., Wright, M., \& Lockett, A. (2004). Critical junctures in the development of university hightech spinout companies. Research Policy, 33(1), 147-175.

Von Hippel, E. (1988). The Sources of Innovation. Oxford University Press.

Von Hippel, E. (1994). 'Sticky information' and the locus of problem solving: Implications for innovation. Management Science, 40(4), 429-439.

Wang, L., \& Zajac, E. J. (2007). Alliance or acquisition? A dyadic perspective on interfirm resource combinations. Strategic Management Journal, 28(13), 1291-1317. 
Wennberg, K., \& DeTienne, D. R. (2014). What do we really mean when we talk about 'exit'? A critical review of research on entrepreneurial exit. International Small Business Journal, 32(1), 4-16.

Wennberg, K., Wiklund, J., DeTienne, D. R., \& Cardon, M. S. (2010). Reconceptualizing entrepreneurial exit: Divergent exit routes and their drivers. Journal of Business Venturing, 25(4), 361-375.

Wennberg, K., Wiklund, J., \& Wright, M. (2011). The effectiveness of university knowledge spillovers: Performance differences between university spinoffs and corporate spinoffs. Research Policy, 40(8), 1128-1143.

Yu, Y., Umashankar, N., \& Rao, V. R. (2016). Choosing the right target: Relative preferences for resource similarity and complementarity in acquisition choice. Strategic Management Journal, 37(8), 1808-1825.

Zaheer, A., Castañer, X., \& Souder, D. (2013). Synergy sources, target autonomy, and integration in acquisitions. Journal of Management, 39(3), 604-632.

Publisher's Note Springer Nature remains neutral with regard to jurisdictional claims in published maps and institutional affiliations.

\section{Authors and Affiliations}

\section{Pamela Adams ${ }^{1} \cdot$ Roberto Fontana ${ }^{2,3} \cdot$ Franco Malerba $^{4}$}

Pamela Adams

pamela.adams@shu.edu

Roberto Fontana

roberto.fontana@unipv.it

1 Department of Management, Stillman School of Business, Seton Hall University, 400 South Orange Ave, South Orange, NJ 07079, USA

2 Department of Economics and Management, University of Pavia, Via San Felice 5, 27100 Pavia, Italy

3 ICRIOS-Bocconi University, Via Roentgen 1, 20136 Milan, Italy

4 Department of Management and Technology, ICRIOS-Bocconi University, Via Roentgen 1, 20136 Milan, Italy 